Florida International University FIU Digital Commons

FIU Electronic Theses and Dissertations

University Graduate School

$11-8-2010$

\title{
Parental Absence and Academic Achievement in Immigrant Students
}

Chrysalis L. Wright

Florida International University, cwrig001@fiu.edu

DOI: $10.25148 /$ etd.FI10120803

Follow this and additional works at: https:// digitalcommons.fiu.edu/etd

Part of the Bilingual, Multilingual, and Multicultural Education Commons, Child Psychology Commons, and the Developmental Psychology Commons

\section{Recommended Citation}

Wright, Chrysalis L., "Parental Absence and Academic Achievement in Immigrant Students" (2010). FIU Electronic Theses and Dissertations. 322.

https://digitalcommons.fiu.edu/etd/322

This work is brought to you for free and open access by the University Graduate School at FIU Digital Commons. It has been accepted for inclusion in FIU Electronic Theses and Dissertations by an authorized administrator of FIU Digital Commons. For more information, please contact dcc@fiu.edu. 


\title{
FLORIDA INTERNATIONAL UNIVERSITY
}

Miami, Florida

\section{PARENTAL ABSENCE AND ACADEMIC ACHIEVEMENT IN IMMIGRANT STUDENTS}

\author{
A dissertation submitted in partial fulfillment of the \\ requirements for the degree of \\ DOCTOR OF PHILOSOPHY \\ in \\ PSYCHOLOGY
}

by

Chrysalis Lamae Wright

2010 
To: Dean Kenneth Furton

College of Arts and Sciences

This dissertation, written by Chrysalis Lamae Wright, and entitled Parental Absence and Academic Achievement in Immigrant Students, having been approved in respect to style and intellectual content, is referred to you for judgment.

We have read this dissertation and recommend that it be approved.

William Kurtines

Marilyn Montgomery

Dionne Stephens

Date of Defense: November 8, 2010

Mary J. Levitt, Major Professor

The dissertation of Chrysalis Lamae Wright is approved.

Dean Kenneth Furton

College of Arts and Sciences

Interim Dean Kevin O’Shea

University Graduate School

Florida International University, 2010

ii 


\section{DEDICATION}

I dedicate this dissertation to Garry, my soul mate, for his complete devotion, support, understanding, and love. Without his presence, all of this would have been impossible. Without his patience and support I would not have been able to complete the program. Thank you for doing what husbands normally do not do and for making me continue when I felt there was no hope or desire. And to my children: Ivy, Micah, Zachia, Azariah, and Iona. Their patience, love, and seeing their future in their eyes helped me to keep going when I did not think I could.

This is also for my mother, Demetria Smith, who watched gracefully as her only child left her hometown in pursuit of her dreams. She was saddened to watch my family and I leave but remained supportive throughout. She repeatedly offered words of encouragement and offered support when she could. I hope that my accomplishment makes her proud; proud to be the mother of the first person in our family to pursue a college education and see it all the way through.

I also dedicate this dissertation to the loving memory of my grandparents, Ethel M. Wright and Clayton F. Wright, both of whom were confident in my ability to do what no other member of my family has done. They were supportive of my goals, understanding of my desires, and loved me unconditionally. In the course of my goal to complete a Ph.D. in Psychology, I lost both of them and struggled to continue in the program because of my grief and pain. I know that both of them would be proud of my accomplishments; not just a Ph.D. in Psychology but accomplishing such an educational endeavor with five lovely children to care for. 


\section{ACKNOWLEDGMENTS}

I would like to thank the members of my committee for their support, patience, understanding, and guidance. Their scholarly direction has been greatly appreciated. Dr. William Kurtines was particularly helpful in guiding me toward the implementation of structural equation modeling. Not only was he extremely helpful as a committee member but he was also a great instructor, opening my eyes to varying aspects of methodology during my first course and first semester in the doctoral program at Florida International University. Dr. Kurtines was the first Professor of Psychology I met at FIU and truly made an impact immediately. Dr. Marilyn Montgomery has been extremely helpful in directing my attention to other areas of expertise, which are related to developmental psychology. She guided my efforts to incorporate educational research into the project and has proven herself to be an expert in the field. Dr. Montgomery's professionalism is something to be admired. Dr. Dionne Stephens has proven to be one of the most inspirational people I have encountered at FIU. Not only did she provide helpful insight regarding the dissertation project along the way, but she also provided much needed support throughout the process. I have come to truly care for Dr. Stephens and not only consider her to be a role model but also a dear friend.

I would like to also thank my major professor, Dr. Mary J. Levitt. Dr. Levitt was extremely helpful in guiding my ideas on analyses as well as guiding me in my writing ability. From my beginning at FIU, Dr. Levitt demonstrated confidence in my abilities to complete the doctoral requirements with flying colors, regardless of the additional responsibilities I have at home. She understood that my family life and children served as motivation and inspiration for me to complete the program. Not only has Dr. Levitt 
passed on her knowledge and passion of the field to me, but she has also passed on her determination, drive, and attention to detail. She truly is an inspiration to me and demonstrates accomplishments I hope to achieve myself one day in the future. Dr. Levitt has become a lifelong mentor whom I will always cherish and hold close to my heart.

Finally, I would like to thank the University Graduate School for awarding my dissertation work the Dissertation Year Fellowship Award. To receive such an award is in itself an honor. The University Graduate School only awards three of these awards annually. This award provides financial support to doctoral students during the data analysis and writing phase of the project. Receipt of the award helped me to focus my efforts and interest to the completion of my dissertation within one year of the award and allowed me the ability to graduate in advance of students who advanced to candidacy at the same time as I did.

I have enjoyed my experience at FIU and, while am happy to be completing the program, am saddened that this chapter in my life is coming to an end. I have learned more about myself and the world than I could have ever imagined. The multicultural atmosphere is amazing and the instructors within the psychology department are stimulating and thoughtful. They have provided me with the tools needed to investigate and examine developmental processes and have inspired me in my research endeavors. 


\title{
ABSTRACT OF THE DISSERTATION
}

\section{PARENTAL ABSENCE AND ACADEMIC ACHIEVEMENT IN IMMIGRANT STUDENTS}

\author{
by \\ Chrysalis Lamae Wright \\ Florida International University, 2010 \\ Miami, Florida \\ Professor Mary J. Levitt, Major Professor
}

Academic achievement and educational expectations as a function of parental absence were examined among 268 newly immigrant elementary, middle, and high-school students from Spanish-speaking countries. Data collected as part of a longitudinal study of adaptation and achievement in newly immigrant students were analyzed. Participants had varying experiences with parental absence, in terms of length of absence, gender of absent parent, and reason for absence. Reasons for parental absence included parental divorce, parental death, and serial migration, a cause unique to immigrant children. Students who experienced parental absence reported lower educational expectations. Students who experienced the death of a parent had lower achievement scores and lower expectations than students who did not experience parental death. Prolonged absence was also important, with students who experienced parental absence for more than one year performing worse than students who had minimal parental separation. In addition, boys who experienced parental absence because of serial migration performed worse academically than boys who did not have this occurrence. Educational expectations were reduced among students who experienced parental absence as a result of the migratory process, especially for younger students. The extent to which parental absence related to 
achievement and expectations through potential mediating factors, such as economic hardship, perceived school support, and parental school involvement was assessed with structural equation modeling. Overall, the model was able to explain some of the relationship between parental absence and the academic achievement and educational expectations of immigrant students from Spanish-speaking countries. 


\section{TABLE OF CONTENTS}

\section{CHAPTER}

I. INTRODUCTION .................................................. 1

Parental Absence Literature: Single Parent Homes and Academic

Outcomes

Factors Associated with the Impact of Parental Absence on

Children.

Academic Achievement among Spanish-speaking Immigrant Students.......... $\quad 7$

Gender of Child........................................................ 11

Language Barriers............................................... 11

School Support................................................ 12

Economic Hardship............................................. 14

Parental School Involvement......................................... 15

Bridging the Gap: Parental Absence, Academic Achievement and Educational Expectations among Immigrant Students................................. 17

Impact of Immigration on the Family................................ 17

Parent Absence and Achievement in Immigrant Students............... 19

Summary and Rationale for the Current Study............................. 21

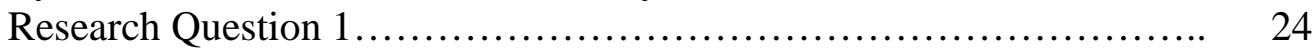

Research Question 2.......................................... 25

Research Question 3........................................ 26

II. METHODS................................................................ 27

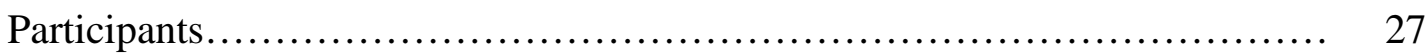

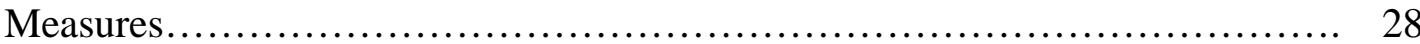

Control Variables..................................................... 28

Experience with Parental Absence....................................... 28

School Support..................................................... 29

Economic Hardship............................................. 29

Parental School Involvement....................................... 29

Student Expectations............................................. 30

Academic Achievement.......................................... 30

Procedure.............................................................. 31

Analyses................................................................ 32

Research Question 1: Parental Absence and Achievement................ 32

Research Question 2: Reasons for Parental Absence and

Achievement........................................................ 32

Research Question 3: Paths through which Parental Absence Relates to

Academic Outcomes............................................. 32

Data Preparation Strategies............................................... 32

Missing Data..................................................... 32 
Non-normality and Outliers....................................... 33

Statistical Power and Sample Size Considerations...................... 33

III. RESULTS ........................................................... 35

Research Question 1: Parental Absence, Academic Achievement, and

Educational Expectations.............................................. 35

Research Question 2: Predicting Academic Achievement and Educational

Expectations........................................................ 36

Intercorrelations of Study Variables................................. 36

Predictors of Academic Achievement and Educational Expectations...... 37

Research Question 3: Paths through which Parental Absence Relates to

Achievement and Expectations............................................ 39

Structural Equation Modeling.................................... 40

Model Evaluation for the Current Study.............................. 41

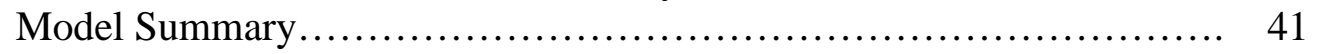

Identification of the Model....................................... 41

Recursive Model.............................................. 42

Assessment of Normality ......................................... 42

Notes for the Model and Model Fit Statistics............................ 43

Standardized and Unstandardized Path Coefficients..................... 44

Total Effects....................................................... 47

IV. DISCUSSION .......................................................... 48

Are there significant differences in immigrant students from parent absent verses dual-parent homes in terms of educational expectations and academic achievement?.

How do various experiences of parental absence affect academic expectations and achievement?.

To what extent does parental absence relate to academic expectations and achievement through potential mediating factors, including economic hardship, school support, and parental involvement?..

Limitations of Study

Difficulties of Cross-cultural Research................................ 57

Inability to Make Casual Statements................................. 57

Limited Generalizability....................................... 58

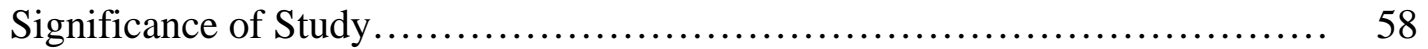

Implications for Future Research....................................... 58

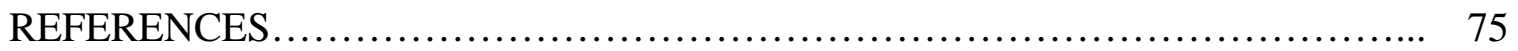

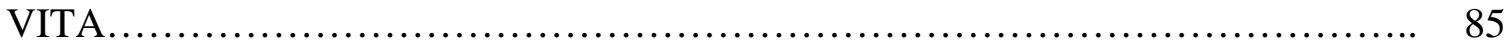


1. Descriptive Statistics for Variables................................... 62

2. Intercorrelations of Study Variables.................................... 64

3. Predicting Academic Achievement: Hierarchical Regression

Analysis............................................................ 65

4. Predicting Educational Expectations: Hierarchical Regression

Analysis................................................................ 66

5. Mardia’s Test of Normality........................................ 67

6. Top Ten Observations in Descending Order of Mahalanolois d-squared Values.............................................................. 68

7. 95\% Confidence Intervals for Unstandardized Path Coefficients............... 69

8. Standardized Path Coefficients for Model............................... 71

9. Total Effects in Model.............................................. 74 


\section{Chapter I}

Introduction

The aim of the current study was to examine the academic achievement and

educational expectations of Spanish-speaking immigrant students who had experienced parental absence. Little research has isolated the immigration process as a cause for parental absence in regard to its impact on the academic achievement of the children involved (Roer-Strier, Striet, Este, Shimoni, \& Clark, 2005; Rousseau, Rufagari, Bagilishya, \& Measham, 2004; Smith, Lalonde, \& Johnson, 2004; Suarez-Orozco, Todorova, \& Louie, 2002). The majority of researchers who have examined the effects of parental absence on academic outcomes have focused on parental divorce as the cause of separation (e.g., Lamb, 1999; McLanahan \& Teitler, 1999). Research on parental absence has focused largely on the absence of the father (e.g., Lamb; McLanahan \& Teitler; Rumbaut, 1994), with studies examining maternal absence being minimal. Immigrant children often experience some form of parental separation during the process of immigration (Suarez-Orozco \& Carhill, 2008). However, while numerous studies have been conducted on the academic achievement of Spanish-speaking immigrant students, very few have examined the effects of parental absence on these outcomes (SuarezOrozco, Rhodes, \& Milburn, 2009; Suarez-Orozco et al., 2010). Parental separation as a consequence of migration is generally mentioned, but ultimately brushed over. Thus, with respect to academic outcomes, a gap exists between the body of research on parental absence and that on Spanish-speaking immigrant students, although a clear connection is evident. 
Historically, the United States has been a country of immigration. In 2007 alone, there were over 1,000,000 immigrants who became legal permanent residents of the United States. Currently 22\% of all children residing in the United States are foreignborn (Suarez-Orozco \& Carhill, 2008) and it has been estimated that by 2040 one-third of American children will have an immigrant parent (Rong \& Priessle, 1998). In addition, it has been estimated that 12 million undocumented immigrants enter the country annually (Suarez-Orozco \& Carhill, 2008). With an estimated 600,000 children migrating to the United States each year with one or both parents (Suarez-Orozco \& Carhill, 2008), it is no surprise that immigrant children are considered the fastest growing segment of the population in America (Suarez-Orozco et al., 2009).

Immigrants from Spanish-speaking countries are the fastest growing immigrant population in the United States. According to the United States Census, the projected growth of the Latino population within the United States is expected to increase from 12\% in 2000 to $51 \%$ by 2050 (U.S. Department of Commerce, 2001). Currently, the state of Florida receives the third largest number of Latino immigrants (U.S. Department of Homeland Security, 2007). The vast majority of Florida's Latino population is found in Miami-Dade and Broward Counties (1,291,737 and 271,652, respectively) (U.S. Census Bureau, 2007), influencing student demographics and characteristics within the public school system of Miami-Dade. According to Florida’s Office of Economic and Demographic Research (2005), 77\% of Florida's students who were born in Cuba attended school in the Miami-Dade School District.

The goal of the current study was to close the gap in our current knowledge of academic outcomes for immigrant students from Spanish-speaking countries by assessing 
the effects of parental absence on academic achievement and educational expectations for Spanish-speaking immigrant students in the Miami-Dade County school district. The following literature review includes an overview of research on (a) parental absence and child academic achievement, (b) academic achievement of Spanish-speaking immigrant students, and (c) links between parental absence and immigration in relation to achievement.

Parental Absence Literature: Single-Parent Homes and Academic Outcomes

Han (2008) describes the family environment as the most important factor in learning and development for children. Research suggests that children from two-parent homes experience psychological and developmental advantages that are not present in single-parent homes. Children raised in dual-parent homes have better psychosocial adjustment (e.g., less internalizing and externalizing behaviors), better achievement in school, higher educational achievement, and less involvement in antisocial and delinquent behavior (Astone \& McLanahan, 1991; Coley, 1998; Hernandez, 2004; Lamb, 1999; Suarez-Orozco et al., 2009). This may be because two-parent homes have greater resources, time, and attention to offer their children (Gibson-Davis, 2008; Suarez-Orozco et al., 2009). Multiple caretakers also are better able to facilitate academic engagement and performance (Suarez-Orozco et al. 2009).

Children in single-parent homes are particularly at a disadvantage because they most often experience a reduction in the number of adult role models who are available to them. The reduction of adult role models, in turn, may result in the child missing out on resources that could have been invested by the absent parent (Heard, 2007). Singleparents may not have the resources necessary for children to attend a suitable learning 
environment (Valencia, 2000) and to attend college (Glenn \& Kramer, 1987). Residing in a single-parent home can be detrimental for the children involved.

According to the National Center for Health Statistics (1998), over 1 million marriages in the United States end in divorce each year, and it has been estimated that 1.5 million children experience divorce annually (Mullett \& Stolberg, 2002). Nearly $40 \%$ of children living in the United States do not reside with their biological fathers (Gillis, 2000).

When a divorce or separation occurs, the family unit often loses at least half of its income. The loss may be significant, considering that it is usually the father, often the main financial provider, who leaves the family unit (Lamb, 1999). Departure of a father may force new, single mothers to enter the workforce more actively. Because these mothers are now working outside of the home more, they have less time to care for, supervise, and give guidance to their children (Lamb, 1999; McLanahan \& Teitler, 1999). Even though these single mothers are working more just to make ends meet, poverty may still be an issue. McLanahan and Teitler note that poverty may affect the emotional wellbeing of the parents, leading to a problematic family life. As noted previously, singlemothers also may have fewer resources to offer their children (e.g., living in neighborhoods with underprivileged public schools), which may impede their children's development and health.

Factors Associated with the Impact of Parental Absence on Children. The effects of parental absence have been associated with a number of factors including (a) child's age, (b) length of parental absence, (c) reason for parental absence, (d) gender of the 
child, and (e) gender of the absent parent. Research on these factors is cited in the following paragraphs.

The age of the child at the time of disruption is thought to be important with respect to child outcomes (Zill, Morrison, \& Coiro, 1993). Parental separation that occurs while children are very young may be more detrimental than one that occurs later in children’s lives (Amato, 1996; McLanahan \& Teitler, 1999). McLanahan and Teitler claim that if the separation occurs in early childhood, children may be more emotionally affected by the experience of parental separation than would older children (see also Zill et al.). However, some argue that waiting until children have reached adolescence to divorce is more detrimental for children than if parents divorced when children were young, especially if children had to endure the break up (McCabe, 1997; McLanahan \& Bumpass, 1988; McLanahan \& Teitler; Sprague \& Kinney, 1997).

The length of the parental absence experience is related to the child's age at the time of parental absence. For instance, children who experience parental absence during childhood are more likely to experience a prolonged period of parental absence than those who experience parental absence during adolescence. Previous research has been extremely limited in the examination of length of parental absence on children's outcomes. For instance, Biller (1970) looked at the length of father absence, ignoring other forms of parental absence experiences, such as mother absence, and concluded that prolonged periods of father absence resulted in detrimental outcomes for boys, such as sexuality confusion, cognitive deficits, and aggressive behavior. This study, however, is outdated and is biased in terms of gender role expectations. 
As noted previously, the majority of existing research on the association between parental absence and academic achievement and educational expectations has been focused on the impact of parental divorce (Astone \& McLanahan, 1991; Coley, 1998; Hernandez, 2004; Lamb, 1999) and the effects of prolonged father absence. Little research has addressed other reasons for parental absence, such as parental death. Studies that have addressed the effects of parental death on academic outcomes, while minimal, have suggested a negative association between the death of a parent and school achievement (Abdelnoor \& Hollins, 2004a; Dowdney, 2000; Grollman, 1967; Van Eerdewegh, Bieri, Parilla \& Clayton, 1982). This negative association may result from the emotional turmoil and disturbed thinking that children often demonstrate after parental death (Adolnoor \& Hollins, 2004b). It has also been documented that the future educational plans of children were postponed after parental death (Adolnoor \& Hollins, 2004b). Parental separation for this reason has also been linked to difficulties in deciding an educational or career path as well as increased college dropout rates (Adolnoor \& Hollins, 2004b).

It has been suggested that the impact of parental absence affects boys and girls quite differently, with boys having more long-term consequences than girls (Conway, Christensen, \& Herlihy, 2003; McCabe, 1997). For instance, boys who experience the absence of their biological father have been found to be more aggressive (Bishop \& Lane, 2000) and involved in more deviant and antisocial behaviors (Bereczkei \& Csanaky, 1996; Coney \& Mackey, 1998; Zill et al., 1993) compared to boys who do not experience parental absence (Coley, 1998). Research also has suggested that boys from parent absent homes have more academic problems than do girls (Coney \& Mackey; 
McLanahan \& Teitler, 1999). McLanahan and Teitler claim that adolescent boys are more likely to participate in delinquent activity, such as skipping school, while girls may engage in behaviors that compromise their future, such as engaging in early sexual activity and becoming pregnant at an early age (see McLanahan \& Bumpass).

The gender of the absent parent is also an important factor to consider when examining the impact of parental absence on child outcomes. Most of the information regarding parental absence is derived from studies that focused on father absence, as fathers are more likely than mothers to be absent from the child's home. Father involvement in the academic lives of their children appears to be significant for their achievement and educational goals. Research has found a positive relationship between father involvement (e.g., parenting style, paternal school involvement, child care) and child academic outcomes (Fagan, 2000). Father absence has been linked to academic problems, particularly for boys (Coney \& Mackey, 1998; McLanahan \& Teitler, 1999). In a rare study that examined the effects of both father absence and mother absence, Heard (2007) found that father changes (e.g., father absence, single-mother home) increased the risk of school disciplinary problems, while mother changes (e.g., mother absence, single-father home) reduced college expectations of the children. Heard also found that, for each year a child lived in either a single-father or single-mother home, there was a substantial reduction in the grade point average of the child. Heard concluded that living in two-parent homes encouraged the study habits and appropriate behavior of adolescents. 
Academic Achievement among Spanish-speaking Immigrant Students

Spanish-speaking immigrant students generally perform well academically (Fuligni, Witkow, \& Garcia, 2005; Witkow \& Fuligni, 2007), but a large segment struggle in school once they have migrated to the United States (Suarez-Orozco et al., 2009). Variation in school performance can be found both within and across sociocultural boundaries (Portes \& Rumbaut, 2001; Rumbaut, 1997).

Post-migration risks experienced in the new country may compound risks to academic success already associated with the migration experience (e.g., cause of migration, process of migration, settlement in United States) (Gil \& Vega, 1996; James, 1997). Stress accompanying immigration can hinder students' adjustment to their new school environment and external community as well as increase their chances of academic failure (Suarez-Orozco et al., 2009). Newly immigrant students not only have to adjust to the United States (Suarez-Orozco, Suárez-Orozco, \& Todorova, 2008), but also have to learn a new language (Suarez-Orozco \& Carhill, 2008), and struggle to complete school requirements (e.g., graduation requirements) (Ruiz-de-Velasco \& Fix, 2001). These adjustments have to be made within the competitive testing environment that exists in American schools today. Additional major life events, such as death in the family, or divorce, only add to the problems experienced by some immigrant families.

Current literature demonstrates that while immigrant students have positive attitudes toward school (Suarez-Orozco \& Suarez-Orozco, 1995), are optimistic about their future (Kao \& Tienda, 1995; Suarez-Orozco, 2001), and have high aspirations for themselves (Fuligini, 1997; Portes \& Rumbaut), many perform poorly on standardized achievement tests, have poor academic grades, are more likely to be behind at least one 
grade level in school, have higher rates of high school dropout (Hernandez, 2004), and lower rates of college attendance (Gandara, 1994; Orfield, 2002) compared to native born students. For instance, nationally $10 \%$ of 16 -year-olds from immigrant families are behind one grade level compared to 8\% of native-born students (Hernandez). Also, while 79\% of native-born children can be expected to complete high school by age 19, only $72 \%$ of immigrant children are expected to have the same outcome (Hernandez). Spanish speaking immigrants have not shown the same achievement advantage and are more likely than other groups to drop out of school (Fuligni, 1997; Hernandez, 2004; Kao \& Tienda, 1995; National Center for Educational Statistics, 2006). Thus, it is especially important to understand the factors that are involved regarding the achievement of these students.

The academic struggles of immigrant students are also recognized at the local level. Florida’s Office of Economic and Demographic Research (2005) has defined poor academic progress as being "two or more grades below modal grade” (p. 19). Seventy percent of students who fit this criterion in Florida were born in the United States with English as their home language. The remaining students were (a) foreign born with English as their second language (14\%), (b) born in the United States with English as their second language (14\%), and (c) foreign born with English as their home language (2\%). Those students who had poor academic progress increased for all groups as they moved from elementary school to middle school to high school. High school students had the largest gap among the different groups, with students with English as their second language having the largest percentage (17.7\%) of students meeting the criteria for poor academic progress. 
Academic achievement of students from immigrant households has been attributed to numerous factors. These include gender of the student (Crul \& Vermeulen, 2003; Portes \& Rumbaut, 2001; Suarez-Orozco \& Qin-Hilliard, 2004; Suarez-Orozco \& Carhill, 2008; Suarez-Orozco et al., 2009; Way, 2004), difficulties with the English language (Genesee \& Gandara, 1999; Hernandez, 2004; Suarez-Orozco \& Carhill; Suarez-Orozco et al., 2009), a problematic school environment (Gaytan et al., 2007; Han, 2008; Suarez-Orozco \& Carhill; Woolley, 2007), economic hardship (Garibaldi, 1997; Roscigno, 2000; Suarez-Orozco \& Carhill; Suarez-Orozco et al., 2010), and reduced parental involvement in the educational process (Barnard, 2004; Hernandez; Gaytan et al.; Kuperminc, Darnell, \& Alvarez-Jimenez, 2007; Martinez, DeGarmo, \& Eddy, 2004; Suarez-Orozco et al., 2010), as well as coming from a single-parent home (Amato \& Sobolewski, 2001; Coley, 1998; Lamb, 1999; Suarez-Orozco et al., 2009; Suarez-Orozco et al., 2010).

It is not just one of these isolated factors that hinder educational success but some combination among them. For instance, in a recent study that examined the educational achievement of immigrant students from Central America, China, Dominican Republic, Haiti, and Mexico, poor academic achievement was linked to pre-migratory difficulties such as parental separation and poor receiving context within the United States (e.g., familial conflict, high crime neighborhood), as well as economic hardship, limited parental involvement and support, and prolonged periods of parental absence (SuarezOrozco et al., 2010). Literature regarding factors associated with academic performance in immigrant students is cited in the following paragraphs. The limited research on 
parent absence in relation to immigrant student achievement is reviewed in a later section.

Gender of Child. Previous research has found a gendered difference in the academic achievement and educational outcomes of immigrant youth. Generally, research has found that girls tend to outperform their male immigrant counterparts (Portes \& Rumbaut, 2001; Suarez-Orozco \& Qin-Hilliard 2004; Suarez-Orozco et al., 2009; Suarez-Orozco et al., 2008). Feliciano and Rumbaut (2005) concluded that patterns of success and failure vary by gender for immigrant students and are achieved through different methods, finding that boys from immigrant households exhibited lower educational and occupational expectations than girls from immigrant households. They also found that immigrant males were less likely than immigrant females to follow a path that is congruent with accomplishing their educational and occupational goals, with immigrant females surpassing males in their educational attainment. Specifically, Feliciano and Rumbaut found that by their mid-20's 37\% of immigrant males and $46 \%$ of immigrant females were either attending college or had earned a college degree.

The gendered difference may be the result of perceived level of school support and level of engagement with the educational environment, which would agree with previous studies. Previous studies have found that immigrant boys tend to view their school environment as less supportive (Way, 2004) and are at greater risk for disengagement from their school (Crul \& Vermeulen, 2003) than immigrant girls.

Language Barriers. Many immigrants who migrate to the United States do not speak English as their first language and many never become proficient in the language. For instance, a recent study found that of first generation immigrant students who had 
been attending school in the United States for seven years, only 7\% developed academic English skills that were comparable to their native-born peers (Suarez-Orozco et al., 2008). Difficulties with the English language pose a problem for academic success, as the immigrant family household is linguistically isolated from the external Englishspeaking society (Hernandez, 2004).

Numerous researchers have concluded that language barriers can be detrimental to the academic success of immigrant students (Genesee \& Gandara, 1999; Hernandez, 2004; Munoz-Sandoval, Cummins, Alvarado, \& Ruef, 1998). Difficulties with the English language may cause the immigrant student to struggle during class, miss valuable information that is presented in class lectures and class room discussions, have difficulty reading required materials, and have problems with academic writing (Suarez-Orozco \& Carhill, 2008). The language barrier can also present challenges for optimal performance on achievement tests (Suarez-Orozco \& Carhill). In fact, Hernandez lists a language barrier as one of the four critical risk factors for immigrant children. The diminished language skills in English can make it very difficult for both Spanish-speaking immigrant students and their parents to effectively communicate with teachers and other school personnel (Hernandez) and may hinder the immigrant students' access to college (SuarezOrozco \& Carhill).

School Support. The school environment serves as a critical factor for the academic achievement of all students, including students from foreign countries. Schools often serve as the students' first contact with the external world (Han, 2008) and are locales of cultural change for immigrant youth, because it is in schools that they meet teachers as well as peers from various backgrounds (Gayton, Carhill, \& Suarez-Orozco, 
2007). The school environment influences students through class instruction, teacher interaction, and peer associations and friendships. Schools also serve as a source of selfesteem (Karatzias, Power, Flemming, \& Lennan, 2002) and social support which can have a protective effect on the well-being of students (Samdal, Nutbeam, Wold, \& Kannas, 1998). Teacher interaction (Burchinal, Peisner-Feinberg, Pianta, \& Howes, 2002) and the structural environment of the school (Crosnoe, 2005) are important factors that influence the academic achievement of students. For optimal success, students need school environments that are stable, academically challenging, and that provide structure and relational warmth (Woolley, 2007).

Research has demonstrated that the composition of the student body, achievement level of the students, and the school's dedication to providing students with an optimal education are all important factors influencing the academic progress of its students (Crosnoe, 2005). It is unfortunate, however, that schools serving low-income, minority, and immigrant students do not generally produce a supportive school environment (Valencia, 2000), thereby harming the potential for academic achievement. It has been found that immigrant students are more likely than native-born students to attend schools that are at a disadvantage (e.g., minority students, overcrowded, inadequate learning materials) (Crosnoe; Suárez-Orozco \& Suárez-Orozco, 2001; Zhou, 1997). Furthermore, many immigrant youth struggle in schools that fail to provide the resources that they need to achieve (Gaytan et al., 2007). Research has also documented that teachers have more negative interactions with students from low-income families and/or schools (Burchinal et. al, 2002). Previous research has suggested that a stressful school environment can directly affect the well-being of students (Karatzias et al., 2002). The school 
environment coupled with economic hardship, pressure on children to assist the family, and immigrant status has been directly related to increased dropout rates for Latino immigrant students (Suarez-Orozco \& Suárez-Orozco, 1995).

Recently, Han (2008) reported that Latino immigrant students were more influenced than non-Latino White students by their school environment in terms of their academic achievement. Specifically, Han found that immigrant students of Latin American origin were more responsive to school-level factors than immigrant students from other origins, such as Asian backgrounds. It was reported that a positive school environment served greater benefits to the academic achievement (e.g., math and reading scores) of disadvantaged Latino students from Mexico. In addition, previous studies have demonstrated that Latino immigrant students can be highly influenced by their peers. For instance, those who experience economic hardship may clique with peers who are resistant to school (James, 1997; Zhou, 1997; Waters, 1997), resulting in a reduction in academic achievement (Barr \& Lacey, 1998; Fuligni, 1998). Poor academic achievement in Latino immigrant students has also been associated with low acculturation, low self esteem (Hernandez \& Charney, 1998; Levitt et al., 1998; 1999), ethnicity, family environment, age at migration, shorter residence in the United States, and associating with peers of the same cultural background (Levitt et al., 1998; 1999; Rumbaut, 1997).

Economic Hardship. Economic hardship has been linked to student academic achievement via school context (Suarez-Orozco \& Carhill, 2008; Valencia, 2000) and parental school involvement (Martinez et al., 2004). Economic hardship has been reported to coexist among other risk factors as well, such as single parenthood and high crime neighborhoods (Suarez-Orozco \& Carhill). Socioeconomic status is so important 
for children that Hernandez (2004) lists economic deprivation as one of the four major risk factors for immigrant children's outcomes. Economic deprivation is not uncommon among immigrant populations. For instance, Suarez-Orozco and Carhill reported that $25 \%$ of the immigrant children in their sample lived below the poverty line and that a total of $37 \%$ reported family difficulties with buying food. They also found that immigrant children were four times more likely to reside in overcrowded homes than native-born children (Suarez-Orozco \& Carhill).

Immigrant children who have experienced economic deprivation, reduced family income, and parental unemployment have been found to be at risk for negative psychological outcomes (Kopala, Esquivel \& Baptiste, 1994; Rumbaut, 1994). This may occur because economic difficulties may impact Latino immigrant parents’ behavior negatively (Siantz, 1997). They may become less nurturing and less attentive to the needs of their children (McLoyd \& Wilson, 1991; Siantz, 1997).

Parental School Involvement. Parental support is vital in promoting children's adjustment after migrating to the United States (Cox \& Harter, 2003) or may serve to buffer the negative effects of post-migration risk (Martinez et al., 2004; Short \& Johnston, 1997). High levels of intergenerational conflict, however, have been linked to poor adjustment (Harker, 2001; Rumbaut, 1994). Immigrant parents face unique circumstances (e.g., economic difficulties) that may compromise their ability to provide support and lead to increased conflict with their children (Waters, 1997).

Parental support for the educational process of their children can be demonstrated by the level of parental school involvement. Research has suggested that parental school involvement is a good predictor of children's academic and social-emotional 
development during the school years (Barnard, 2004). Teacher-parent communication is vital to the academic achievement of all students, especially immigrant students (Hernandez, 2004). However, many immigrant parents are unable to be actively involved with their children's education because of their own limited education and difficulties with the English language (Gaytan et al., 2007). The National Center for Educational Statistics (2003) reported that Latino parents were less likely than their white counterparts to attend school meetings and events, volunteer at their children's school, and serve on school communities.

More recently, Kuperminc et. al (2008) found that parental school involvement was related to academic adjustment for high school immigrant students more than middle school immigrant students. Immigrant parents, however, seemed to be more involved while their children were in middle school, with parental school involvement declining as their children moved through the educational system. Parental school involvement was associated with teacher expectations for immigrant high school students but not middle school students. The impact of parental school involvement on student grades was important in high school but not in middle school.

Studies have shown that parents who emphasize academic achievement have children who are more likely to have higher academic achievement, a goal to attend college, and to graduate from high school (Astone \& McLanahan, 1991). However, parental socialization and transference of academic importance likely requires long-term contact with parents (Hao \& Xie, 2002). Therefore, it may be important for children to spend extended time with both parents so that parents can successfully socialize their children for educational achievement. When comparing the involvement of Latino 
fathers to non-Latino white fathers, Toth and Xu (1999) suggested that Latino fathers spend more time with their children than their non-Latino white counterparts. The level of paternal involvement of Latino fathers has been found to be associated with socioeconomic status and the fathers' employment status (Landale \& Oropesa, 2001). Bridging the Gap: Parental Absence, Academic Achievement and Educational Expectations among Immigrant Students

Literature focused specifically on the effects of parental absence on immigrant students is reviewed in this section. The impact of immigration on the family is considered first, followed by a review of the limited literature on parent absence and achievement in Spanish speaking immigrant students.

Impact of Immigration on the Family. Immigration can be considered an intense life transition that requires tremendous adaptation (Coll \& Magnuson, 1997; Laosa, 1997; Rumbaut, 1997; Suarez-Orozco \& Suares-Orozco, 2001). The process of immigration can have a dramatic effect on the family unit, as well as individual family members. It impacts both how the parents parent their children (Smith et al., 2004) and how the children adapt to their new environment. For children, parental figures tend to be the primary source of support (Furman \& Buhrmester, 1985). However, the disruptions accompanying immigration may reduce parents' ability to provide adequate support to their children. Parent-child conflict may also increase during this time, impacting the adjustment of children even more (Siantz, 1997). Furthermore, migration can leave the child without one or both parents, which may lead to the child experiencing a great reduction in the level of parental support, as well as tense familial relationships (Waters; Zhou, 1997). 
Previous research has demonstrated how a familial structural change can be emotionally stressful for the entire family (Wallerstein \& Kelly, 1980). Immigration, itself, can cause a familial structural change. Often, the process of immigration leaves the family separated, with one or several family members going to the new country to establish a home, while the remaining family members wait in the mother country before migrating (Rousseau et al., 2004). The reunion of the family may take several years after the first family member left for the new country (Rousseau et al., 2004). Once the family has been reunited, family relationships that were disengaged need to be reestablished (Gaytan et al., 2007). Not only does the child have to become reacquainted with family members who were left behind or who migrated ahead of the child, but there may also be new additions to the family unit that the child encounters, such as step parents, step siblings, or new siblings (Gaytan et al., 2007). These changes within the family unit (e.g., parent child separations, new additions to the family, postponed reunions) demonstrate the enormous diversity that exists among recent immigrant families, which has important implications for the development and adaptation of immigrant youth (Gaytan et al., 2007).

Because of the extended time that parents and children may be separated during the immigration process, their reunion may not be as pleasant as either had hoped. Studies have shown that familial separations due to immigration can result in problems within the family structure as well as psychological distress (Smith et al., 2004). SuarezOrozco et al. (2002) reported no relationship between length of familial separation due to immigration and psychological symptoms. They did, however, report that the majority of the children in their sample had experienced separation from one or both parents during 
immigration and that children who arrived to their new country with their entire family, having experienced no familial separation, were less likely to report depressive symptoms than those children who experienced familial separation. In a similar study, Gaytan et al. (2007) reported that $85 \%$ of their sample of immigrant students reported some form of parent child separation during the immigration process. The extent to which these serial migration experiences might affect school achievement is unknown.

Parent Absence and Achievement in Immigrant Students. Previous research has demonstrated that the absence of either parent can have detrimental effects on the academic achievement of immigrant students. For instance, maternal and paternal absence have been associated with reduced academic success, with prolonged periods of paternal absence being more detrimental to child outcomes (Suarez-Orozco et al., 2010). Rumbaut (1994) found that when the father was absent, immigrant children reported more psychological problems than immigrant children with the father in the home. Hernandez (2004) lists living in a one-parent family as one of the four main determinants of immigrant child outcomes.

As noted previously, serial migration is a pervasive cause of parental absence in immigrant populations, but research that has addressed the academic achievement of immigrant students has only touched on the effects of parental separation due to serial migration. Little research has specified serial migration as a cause of parental absence for immigrant students (Suarez-Orozco et al., 2009; Suarez-Orozco et al., 2010). However, as suggested by Suarez-Orozco and Carhill (2008), one of the primary goals of research on immigrant students should be to capture the various migratory experiences. 
Although immigrant children often experience parental separation as a result of serial migration, an experience unique to them, they may also experience parental absence before or after the family has migrated to the new country for reasons similar to those for native born children. Immigrant families may break up (e.g., separate, divorce) for a variety of reasons, exposing children to prolonged periods of parental absence. It is important to examine the reason(s) for parental absence because parental absence may be viewed differently by those who have experienced parental divorce than by those who experience parental absence for other reasons (Lamb). For example, children who have experienced the divorce of their parents may have difficulty dealing with the separation of their parents, as well as events or circumstances that occur after the separation (e.g., reduction in family income, remarriage of the custodial and noncustodial parent). Children who lose a parent as a result of death may view the separation as inevitable but may be overtaken by grief, instead of anger or resentment. Those who experience parental absence because of the immigration process may view the absence as only temporary, being a necessary step in establishing a home in the new country (Rousseau et al., 2004).

It is also important to examine the effects of parent absence on academic outcomes in the context of other factors known to affect the achievement of Spanishspeaking immigrant students. Battle (2002), for example, found that economic deprivation was more important for academic achievement in Latino immigrant students than family configuration. Battle reported that educational attainment was related to family status (e.g., single-parent, two-parent home) when students were two years out of 
high school but that economic hardship was more predictive than family configuration during high school and after.

\section{Summary and Rationale for the Current Study}

Despite the value of the research summarized above, our understanding of the factors that can impede or promote the academic achievement and educational expectations of Spanish-speaking immigrant students in the United States has been constrained by the limitations of many previous studies. Previous research has indicated that Latino immigrant students are at risk for low academic achievement and reduced educational expectations (Hernandez, 2004; National Center for Educational Statistics, 2006). Previous research has also reported a number of factors that are influential with respect to the academic achievement of Latino immigrant students. These factors include gender of the child, language barriers, an unsupportive school environment, economic deprivation, limited parental school involvement, and residing in a single-parent home (Amato \& Sobolewski, 2001; Barnard, 2004; Genesse \& Gandara, 1999; Hernandez; Kuperminc et. al, 2007; Lamb, 1999; Martinez et al., 2004; Rivas-Drake \& Mooney, 2008).

Thus, parental absence has been found to relate to low academic achievement and expectations, but little is known about how the various reasons for parental absence affect academic achievement in Spanish-speaking immigrant children. Parental absence in immigrant families may be caused for a variety of reasons. Immigrant children may experience parental absence for reasons different from native-born children, such as the serial migration of family members (Rousseau et al., 2004), or for reasons shared by nonimmigrant children, such as parental separation or divorce (Mullett \& Stolberg, 
2002), and parental death. Parent absence that results from the immigration process may be viewed quite differently by the children involved than parent absence due to parental separation or divorce and parental death. Previous research has not been specific as to how different reasons for parent absence are viewed by children and how they might affect the academic achievement and life-course of the children with this experience.

Also, the paths through which parental absence affects academic achievement for immigrant students have not been specified, although parental absence in general has been associated with a number of factors related to low academic achievement and reduced educational aspirations. For instance, father-absence has been found to be related to a reduction in socioeconomic status (Heard, 2007), an unsupportive school environment (Glenn \& Kramer, 1987; Valencia, 2000), and a reduction in parental school involvement (McLanahan \& Carlson, 2002), all of which are correlated with poor academic achievement. The factors associated with the academic achievement of Latino immigrant students in particular (e.g., supportive school environment, economic hardship, parental school involvement) are also related to parental absence.

To address some of the limitations of previous research, the current study examined the relation between parental absence and the academic achievement and educational expectations of children from immigrant households while controlling for such factors as (a) child's age, (b) gender of the child, and (c) proficiency with the English language. Achievement outcomes are known to vary by student age, so it is necessary to control for age when predicting achievement. Age of the child may also interact with parental absence, as younger children may be more affected by separation 
than older children or vice versa (Amato, 1996; McCabe, 1997; McLanahan \& Bumpass, 1988; McLanahan \& Teitler; Sprague \& Kinney, 1997).

Also, boys generally have more academic problems than girls (Portes \& Rumbaut, 2001; Suarez-Orozco \& Qin-Hilliard 2004; Suarez-Orozco et al., 2009; Suarez-Orozco et al., 2008). Immigrant girls typically perform better than boys (Feliciano and Rumbaut, 2005). Boys tend to view the school environment as less supportive and have lower expectations than girls (Way, 2004). Girls are also more likely to go to college than boys (Feliciano and Rumbaut, 2005). Thus, it is also necessary to control for child gender in predicting achievement. Child gender may also interact with parental absence and with the gender of the absent parent, as boys and girls may respond differently to separation and to the absence of mother or father. Father absence has been linked to low achievement, particularly for boys (Coney \& Mackey, 1998; McLanahan \& Teitler, 1999).

English language proficiency is also known to affect academic outcomes for immigrant students (Genesee \& Gandara, 1999; Hernandez, 2004; Munoz-Sandoval, Cummins, Alvarado, \& Ruef, 1998). Thus, it is necessary to control for language proficiency in predicting achievement as well.

Parental absence was examined more extensively to determine how the following variables predicted the academic achievement and educational expectations of the immigrant children involved: (a) reason for parental absence, (b) gender of absent parent, and (c) length of parental absence. Also, potential mediators of the influence of parental absence on academic achievement and educational expectations were examined. The following variables were examined as mediating factors: (a) parental school involvement, 
(b) family economic hardship, and (c) students' perceived school support. Thus, parental absence was expected to be associated with greater economic hardship, lower parental involvement, and a less supportive school environment. Academic achievement indicators included teacher rated adaptation and competence, along with grade point average (GPA) and conduct and effort scores obtained from centralized student records. Student records also supplied information regarding student's grade level, gender, and English-language proficiency scores, which were control factors in the study. In addition to academic achievement indices, the following educational expectations were examined as outcome variables: (a) anticipated high school graduation, (b) anticipated college attendance, and (c) anticipated career choice.

Participants in the current study included 268 Spanish-speaking immigrant students (105 Cuban, 77 Columbian, 86 Argentinean) with varying experiences of parental absence, in terms of length of absence, gender of absent parent, and reasons for absence (immigration, separation/divorce, parental death). Participants were interviewed at school in three consecutive years as part of a larger study of immigrant student adaptation. Parents completed surveys at home that included data on parental absence. Data for the present study were drawn primarily from the third year interviews and parent surveys, as that is when detailed information regarding parent absence was gathered. The following research questions were addressed:

Research Question 1: Are there significant differences in Spanish-speaking immigrant students from parent absent versus dual-parent homes in terms of educational expectations and academic achievement? 
Children in two-parent homes generally have higher educational achievement than those from single parent homes. However, this conclusion is based largely on data from divorced or unwed populations (Astone \& McLanahan, 1991; Coley, 1998; Hernandez, 2004; Lamb, 1999; McLanahan \& Teitler, 1999). The first research question addressed whether the same was true for Spanish-speaking immigrant students in the current study. It was hypothesized that participants from parent absent homes would demonstrate poorer academic achievement and lower educational expectations than students from dual-parent homes.

Research Question 2: How do various experiences of parental absence, including reason for absence (immigration, separation/divorce, parental death), gender of absent parent, and length of absence affect academic expectations and achievement?

In terms of reason for parental absence, parental divorce and the death of a parent have been linked to negative academic outcomes (Astone \& McLanahan, 1991; Abdelnoor \& Hollins, 2004a; Coley, 1998; Dowdney, 2000; Grollman, 1967; Hernandez, 2004; Lamb, 1999; Van Eerdewegh, Bieri, Parilla \& Clayton, 1982). Serial migration of families is a primary reason for parental absence in immigrant students (Gaytan et al., 2007; Rousseau et al., 2004; Suarez-Orozco et al., 2002) and has not been studied in relation to educational outcomes. Father absence has been linked to academic problems (Lamb, 1999; McLanahan \& Teitler, 1999; Rumbaut, 1994) but mother absence has rarely been addressed. In a study that examined the effects of both father and mother absence, father absence increased the risk of school disciplinary problems, while mother absence reduced college expectations (Heard, 2007). In addition, previous research has been limited on the effects of length of parental absence, but longer absences may be 
more detrimental to academic outcomes. In essence, the length of parental absence is related to the child's age at the time of separation. It was hypothesized that each of these factors would have some relation to academic achievement and educational expectations.

Research Question 3: To what extent does parental absence relate to academic expectations and achievement through potential mediating factors, including economic hardship, school support, and parental involvement?

Immigrant students often experience economic hardship and the experience of parental absence may increase this risk. Economic hardship may be linked directly to student achievement or indirectly through its relation to school context and parental school involvement (Suarez-Orozco \& Carhill, 2008; Martinez et al., 2004; Valencia, 2000). Schools serving low-income, minority, and immigrant students do not generally produce a supportive school environment, harming the potential for academic achievement (Valencia, 2000). Latino immigrant students may be more influenced by their school environment than other students (Han, 2008). Parental absence may be linked to lower school support directly or indirectly through increased economic hardship (Waters, 1997). Parental involvement is a good predictor of children’s academic achievement and educational expectations during the school years. Parental absence may be linked to lower achievement and expectations through reduced parental involvement. It was hypothesized that the influence of parental absence on academic achievement and educational expectations would be mediated by (a) parental school involvement, (b) economic hardship, and (c) school support. The proposed model of effects can be found in Figure 1. 


\section{Chapter II}

\section{Methods}

\section{Participants}

Archival data were used for analyses in the current study. Data came from a three-year longitudinal study focused on the school adaptation of newly-immigrant elementary, middle, and high-school students. Participants were drawn from over 100 different public schools in Miami-Dade County. The subset of participants assessed included 268 Spanish-speaking immigrant students from Cuba $(n=105)$, Columbia $(n=$ 77), and Argentina $(n=86)$ for whom complete data were available in the third year of the project, when parents were queried about their children's experiences with parental absence. These students represented the largest Latino groups migrating to South Florida at the time of the study. They were selected randomly from a list of all students from these countries who were entering the school system in the $3^{\text {rd }}, 6^{\text {th }}$, or $9^{\text {th }}$ grades in the first year of the project. They had been in the U.S. for less than one year.

Ninety one participants (34\%) were in elementary school, 99 (37\%) were in middle school, and 78 (29\%) were in high school in the first year of the project. Fiftyone percent $(n=137)$ of participants were male and $49 \%(n=131)$ were female. The majority of participants $(72 \%, n=193)$ had experienced some form of parental absence. Thirty eight percent $(n=101)$ experienced parental absence that resulted from serial migration to the United States. Another 7\% $(n=19)$ experienced parental absence because of the divorce of their parents. Twenty-three percent $(n=62)$ experienced parental absence because of both serial migration and parental divorce. Another 6\% $(n=$ 16) experienced parental absence following the death of a parent. The majority of 
participants who experienced parental absence, experienced the absence of their father (44\%, $n=117)$. Eleven participants (4\%) experienced the absence of their mother and $10 \%(n=26)$ experienced the absence of both of their parents at some point. Fifty-one percent $(n=99)$ experienced prolonged parental absence $(>1$ year $)$ and $37 \%(n=71)$ experienced limited parental absence ( $<1$ year).

\section{Measures}

Student and parent surveys were completed in each year of the project. Measures were translated by project personnel fluent in the language and dialects of the participants. In consultation with the project directors, at least two staff members translated and back-translated each measure to make sure that the measures held their meaning across languages. Needed adjustments were made to maintain uniformity and to ensure that items were culturally appropriate across interviews of students from different countries. The following measures contained in the data set were used in analyses.

Control Variables. Initial grade level of student $(3,6,9)$, gender of student, and proficiency with the English language $(1=$ no English, 5 = fluent $)$ were obtained from public school records. These variables were used as controls to assess the relation of parental absence to achievement and expectations independently of these factors. Grade level and student gender were also used in interactions terms with the parent absence variables to determine whether the effects of parental absence varied by age or gender.

Experience with Parental Absence. Parental absence was calculated based on answers to questions that assessed (a) parents marital status (asked of parents at time 1, time 2, and time 3) (i.e., married, separated, divorced, widowed, living in marriage-like relationship, never married), (b) serial migration (asked of students at time 1) (i.e., child 
came to the United States alone, child came to the United States with others, who came before the child, who came with the child), and (c) parents location in relation to the child (asked of students at time 1, time 2, time 3) (i.e., in house with child, some other place in the United States, in home country). From these questions gender of the absent parent, length of absence, and reason for absence were identified.

School Support. A nine-item scale of students’ perceived school support from the Year 2 student survey, adapted from a scale used by Suarez-Orozco and Suarez-Orozco for a comparable study of recent immigrants (in progress), was used to index the level of perceived school support. Example items are "Do you feel there is at least one adult in school you can always count on?” and “Do you feel that school is a lonely place where no one cares about you?” Responses were dichotomous $(1=$ Yes, $2=\mathrm{No})$ and negative items were reverse coded. The sum of the items in this scale was used in analyses. Thus, higher scores indicate better school support. Alpha reliability for the school support measure was .65.

Economic Hardship. Economic hardship was assessed with a single question, asked of parents three different times (time 1, time 2, time 3): “How often does your family have problems paying for things that the family really needs, like food, clothing, or rent?” Responses range from 1 (never) to 5 (almost always). Answers to these three questions were averaged to develop a mean economic hardship indicator. The overall economic hardship variable was used in analyses.

Parental School Involvement. Three questions asked of parents' were used to assess parents’ level of school involvement. These include (1) “How often have you attended activities at your child's school in the past year, such as parent meetings, athletic 
activities, awards ceremonies, performances, cultural events, or other school programs,” with responses ranging from 1 (almost always) to 5 (never), (2) "How often do you check on whether your child has done his/her homework," and (3) "How often do you help your child with his/her homework," with responses ranging from 1 (never) to 5 (almost always). Responses for question 1 were reversed scored. Scores were then averaged to derive an overall mean score for parental school involvement that was used in analyses. Alpha reliability for parental school involvement was .67.

Student Expectations. Student educational expectations were measured with three items assessing students' expectations that they will graduate from high school, attend college, and achieve their career goals. Specifically these items asked, "How sure are you that you will graduate from high school," "How sure are you that you will go to college," and "How sure are you that you will have the job that you want?" Responses range from 1 (not at all sure) to 4 (extremely sure). These responses were averaged to derive an overall mean educational expectations score. The overall score was used in analyses. Alpha reliability for student expectations was .79.

Academic Achievement. Academic achievement indicators included grade point average and conduct and effort scores obtained from centralized student records. Grade point average was calculated by averaging end-of-year reading and math grades, which were assigned numeric equivalents $(4=A ; 0=F)$. Teacher rated adaptation and competence scores were also used as a measure of academic achievement. To measure school adaptation, teachers were asked to rate their students on 14- item scale developed by Alexander, Entwistle, and Dauber (1993). The scale included items assessing the extent to which observed behaviors described the child, such as (1) happy mood, (2) 
timid, afraid, (3) creative, (4) keeps to self, and (5) enthusiastic. Response options ranged from 1 = exactly like this child to $6=$ not at all like this child. Teachers also completed four items comparing their students to typical pupils of the same age from the Teacher Report Form of the Child Behavior Checklist (CBCL) (Edelbrock \& Achenbach, 1984) to assess student competence. Items included (1) "How hard is he/she working," (2) How appropriately is he/she behaving,” (3) "How much is he/she learning,” and (4) How happy is he/she?” Response options ranged from $1=$ much less to $7=$ much more . The Year 3 achievement measures were transformed to $z$ scores and then averaged to create a mean score for overall academic achievement. The overall academic achievement score was used in analyses. Alpha reliability for academic achievement was 88 .

Procedure

Potential participants were contacted and screened for eligibility (residing less than a year in the U. S.) by an interviewer fluent in Spanish. Eligible participants were given information concerning the study, along with parent permission and child assent forms. If the student returned signed consent and assent forms to the interviewer at a scheduled appointment time, the student was interviewed individually in a quiet school location. Participants were re-interviewed one and two years later. The mean interview time was approximately 45 minutes for each session. Children took surveys home for parents to complete and return by mail. Follow-up telephone calls were made to parents for surveys that were not returned and parents were given the option of answering by phone. Very few parents (15 or fewer in each year) answered by phone. Children were 
given small prizes for participating and parents were given supermarket gift certificates for completing parent surveys.

Analyses

Preliminary analyses were conducted to assess the reliability, distributional characteristics, and intercorrelations of measures. The main analyses conducted relative to each research question are described below.

Research Question 1: Parental Absence and Achievement. A multivariate analysis of variance (MANOVA) was first conducted to determine if there was a significant difference in the academic achievement and educational expectations of immigrant students from parent absent versus dual-parent households.

Research Question 2: Reasons for Parental Absence and Achievement. The extent to which various experiences of parental absence, including reason for absence (immigration, separation/divorce, parental death), gender of absent parent, and length of absence affect academic achievement and educational expectations was assessed in a hierarchical regression model.

Research Question 3: Paths through which Parental Absence Relates to Achievement Outcomes. The extent to which parental absence relates to academic expectations and achievement through potential mediating factors, including economic deprivation, school support, and parental school involvement was assessed with structural equation modeling (SEM).

\section{Data Preparation Strategies}

Missing Data. Missing data were minimal (<10\%) for most variables and were estimated using the Full Information Maximum Likelihood (FIML) method. For those 
variables containing missing values, a multiple imputation approach was used with five imputation data sets. The imputations were performed with the computer program Amelia (King, Honaker, Joseph, \& Scheve, 2001). The imputed data set was then used in analyses.

Non-normality and Outliers. Prior to all major analyses, data were analyzed for outliers and non-normality. Multivariate normality was evaluated using Mardia’s test for multivariate normality. In addition, univariate indices of skewness and kurtosis were examined to determine if the absolute value of any of these indices was greater than 2.0. In the current study, non-normality was found to be a problem. For instance, the kurtosis value for school support was 3.93, greater than the 2.0 requirement. Therefore, in the structural equation analysis, bootstrapping with 2000 iterations was utilized to remedy this issue.

Statistical Power and Sample Size Considerations. In general, the outcome variables were continuous in nature and could be evaluated using means. For a two group comparison of independent means, the necessary sample size to detect a mean difference corresponding to a medium effect size $(d=0.50)$ as defined by Cohen $(1988)$, with a two tailed alpha level of 0.05 , and statistical power of 0.80 is 65 per group. The final sample size was over 65 per group for the main parent absent verses not absent groups (75 and 193). Therefore, the study was adequately powered for single degree of freedom mean contrasts.

To determine an appropriate sample size, structural equation modeling requires that in addition to statistical power, issues of the stability of the covariance matrix and the use of asymptotic theory be taken into account. In terms of power, it is difficult to 
evaluate the power associated with specific path coefficients in complex SEM models because of the large number of assumptions about population parameters that must be made. A rough approximation of power can be obtained by using a limited information approach with variables of the path models implied by the proposed model. This permits the use of traditional power analysis software to gain a sense of sample size demands (Jaccard \& Wan, 1996). For example, for a multiple regression analysis with 7 predictors where the squared multiple correlation is 0.25 and where one wants to detect a predictor that accounts for at least $5 \%$ unique variance in the outcome, the required sample size to achieve power of 0.80 is approximately 175 . The projected final sample size of approximately 268 produced adequate statistical power. 


\section{Chapter III}

Results

The analyses reported in this section were conducted to answer the three research questions posed in the introduction. The results related to each question are described in the following sections. Descriptive statistics for the sample for all measures used in the analyses can be found in Table 1.

Research Question 1: Parental Absence, Academic Achievement, and Educational

\section{Expectations}

A multivariate analysis of variance (MANOVA) was conducted to determine what, if any, significant differences existed for academic achievement and educational expectations when students experienced parental absence. The overall MANOVA was marginally significant for the experience of parental absence, $F(2,265)=2.87, p=.06$. Univariate tests revealed a significant effect of parental absence for educational expectations, $F(1,266)=5.64, p<.02$, but not for academic achievement, $F(1,266)=$ 1.16, $p<.30$. For educational expectations, students who experienced parental absence reported lower expectations $(M=3.16, S D=.66)$ than students who did not experience the absence of a parent $(M=3.36, S D=.60)$. For academic achievement, while not statistically significant, students who experienced parental absence had lower achievement $(M=.10, S D=.74)$ than those who did not experience parental absence $(M$ $=.22, S D=.88)$. 


\section{Research Question 2: Predicting Academic Achievement and Educational Expectations}

Intercorrelations of Study Variable

Intercorrelations of the study variables are presented in Table 2. There were some significant correlations of the control variables of grade level, gender, and English language proficiency of child with academic achievement and educational expectations. Females had higher academic achievement than males and those more proficient with the English language had higher academic achievement and educational expectations.

Reason for parental absence variables demonstrated intercorrelations among factors related to parental absence and academic achievement. It was unlikely for participants to experience both parental divorce as well as serial migration, even though there were participants who experienced both as dual causes for parental absence. Those who experienced parental divorce and those who experienced serial migration were more likely to experience the absence of their father. Those who experienced parental divorce were more likely to experience prolonged parental absence. Those who experienced the death of a parent were less likely to experience serial migration as well. However, there were some participants who experienced parental absence for all three reasons. Those who experienced the death of a parent were more likely to experience the absence of both parents and to encounter prolonged absence. The experience of parental death was also negatively related to academic achievement, with students who experienced parental death having lower achievement than those who did not experience the death of a parent. Parental divorce and serial migration as dual causes of parental absence intercorrelated with the absence of the father as well as the absence of both parents and prolonged parental absence. 
Factors related to parental absence were also correlated with coexisting factors related to the parental absence experience and academic achievement and educational expectations. Prolonged parental absence was more likely to occur with the absence of the father as well as the absence of both parents. Prolonged parental absence was also linked to reduced academic achievement and lower educational expectations. Maternal absence was negatively correlated with paternal absence and paternal absence was negatively correlated with the absence of both parents. The absence of both parents was linked to lower academic achievement.

Results also indicated that the outcome measures were intercorrelated. Educational expectations were found to be positively correlated with academic achievement in that those who had higher expectations also performed better in school.

Predictors of Academic Achievement and Educational Expectations. Hierarchical multiple-regression analyses were conducted for academic achievement and educational expectations. Hierarchical regression adds predictors to the regression model in blocks, or stages. The control variables of gender of the child, grade level of the child, and English language proficiency were entered into the first block of the model. Reason for parental absence (i.e., serial migration, parental divorce, both serial migration and parental divorce, parental death) was entered into the second block. Reason for absence was dummy coded as three variables $(1=$ serial migration, $0=$ no serial migration; $1=$ divorce, $0=$ no divorce, $1=$ parental death, $0=$ no parental death). The third block added the length of parental absence variable. Dummy-coded gender of the absent parent variables (i.e., mom, dad, both parents) were entered into the fourth block of the model. The fifth and last block of the model entered interaction terms of interest into the model 
(i.e., grade $\mathrm{X}$ reason of absence, grade $\mathrm{X}$ parent gender, child's gender $\mathrm{X}$ reason for absence, child's gender X parent gender). Both academic achievement and educational expectations were tested with the same regression model. Results for the hierarchical regression models for academic achievement are reported in Table 3 and for educational expectations in Table 4.

For academic achievement, gender and language proficiency were significant predictors. Girls performed better than boys and students more proficient with the English language performed better than those struggling with language communication. The experience of parental absence because of parental death was also significant for academic achievement, with those having this experience having lower academic achievement than those who did not experience the death of a parent. The length of parental absence was marginally significant for academic achievement, with students having prolonged experience with parental absence performing worse than students who did not experience parental absence for long periods of time. The absence of both parents was also marginally significant for academic achievement, with students experiencing the absence of both parents performing worse than students who did not experience the absence of both their mother and father. Results indicated an interaction effect of gender and parental absence associated with serial migration for academic achievement. Follow up regression analyses indicated that boys who experienced parental absence that resulted from serial migration performed worse academically than boys who did not have this experience $(b=-.21, p<.05)$, whereas there was no significant effect of serial migration for girls $(b=.11, p>.05)$. 
For educational expectations, language proficiency was marginally significant, with students more proficient with the English language having higher expectations than those who were not as proficient with the English language. Parental absence resulting from serial migration was also significant for educational expectations, with students experiencing parental absence resulting from serial migration having lower educational expectations than students who did not experience parental absence because of the migratory process. Results were similar for students who experienced parental death; those who experienced parental death reported lower educational expectations than students who did not experience the death of a parent. Results indicated an interaction effect of grade level and parental absence related to serial migration for educational expectations. Follow up regression analyses indicated that elementary school students ( $b$ $=-.51, p<.01)$ and middle school students $(b=-.35, p<.05)$, but not high school students $(b=.22, p>.05)$, who experienced parental absence that resulted from serial migration reported lower educational expectations than students who did not experience parental absence as a result of serial migration.

Research Question 3: Paths through which Parental Absence Relates to Achievement and Expectations

The extent to which parental absence relates to academic achievement and educational expectations through potential mediating factors, including economic deprivation, school support, and parental school involvement was assessed with structural equation modeling (SEM). Structural equation modeling was used to test the proposed causal model (Figure 1). 
Structural Equation Modeling. The SEM framework represents the integration of the factor analytic model (i.e. measurement model) and path analytic model. Structural equation modeling takes a confirmatory approach in specifying that causal processes can be represented by a series of regression equations and tested for fit to the observed data (Byrne, 2001). It utilizes a full information estimation approach in which the path coefficients in all equations in the model are estimated simultaneously and tested for statistical significance (Jaccard, 2010). Global model fit is evaluated independently of the significance tests of the path coefficients. Thus, pairing SEM with the examination of the academic achievement and educational expectations of immigrant students from Spanish-speaking countries as a function of parental absence offers a plausible method for representing and evaluating the causal processes underlying academic achievement and expectations by allowing (1) evaluation of the degree to which the proposed model fits the data at the global level and (2) examination of the specific hypothesized mediated relationships.

Following the recommendations of Bollen and Long (1993), a variety of global fit indices were used to assess model fit. These include indices of absolute fit, indices of relative fit and indices of fit with a penalty function for lack of parsimony. First, the chisquare and its probability value (p-value) were examined. The higher the p-value is, the closer the fit between the hypothesized model and model fit (Byrne, 2001), with a target p-value of greater than .05. The comparative fit index (CFI) is an index of fit based on the comparison of the hypothesized model with the independence model. A CFI value of greater than .95 indicates model fit. The root mean square error of approximation (RMSEA) accounts for the error of approximation in the population. An RMSEA of less 
than .08 indicates model fit. The standardized root mean square residual (standardized RMR) is the average value of standardized residuals derived from fitting the variancecovariance matrix of the hypothesized model to that of the sample data (Byrne, 2001). A standardized RMR of .05 or less indicates model fit.

In addition to the global fit indices, more focused tests of fit were pursued. These include the examination of the standardized residual covariances, which should be between -2.00 and 2.00, and modification indices, which should be less than 4.00 .

Model Evaluation for the Current Study. Model fit was evaluated using AMOS 17.0 software. The proposed model was a good fitting model for the current data set. To ease the presentation and evaluation of the model examined in the current study, results are given in the order that they are presented in the AMOS output.

Model Summary. Consistent with the path diagram presented in Figure 1, overall academic achievement and average educational expectations served as observed variables and operated as dependent variables. All other factors and error terms are independent variables in the model.

Identification of the Model. The model had 9 observed variables. Exogenous variables were the control variables (child gender, grade level, English language proficiency $)$ and the parental absence variable $(1=$ absent, $0=$ not absent $)$. Variables specified as mediators were parental school involvement, economic hardship, and perceived school support. The achievement and expectations variables were specified as outcomes with a direct path from educational expectations to academic achievement. There were a total of 45 distinct sample moments with 42 parameters needing to be estimated. The model was an over-identified model with 3 degrees of freedom (i.e., 45- 
42). At a conceptual level, an over-identified model is one where the number of parameters to be estimated is less than the number of data points or degrees of freedom available, including the variances and covariances of the observed variables. Overidentified models have positive degrees of freedom, which allow researchers to evaluate and to reject null hypotheses, if fitting.

Recursive Model. The model was listed by AMOS as being recursive. A recursive model is one in which no variable has an (indirect) effect on itself. That is, in the path diagram of the model, it is not possible to start at some variable and, by following a path of single-headed arrows, return to the original variable.

Assessment of Normality. Structural equation modeling requires data used in analyses to: (a) be measured on a continuous scale, and (b) have a multivariate normal distribution (Byrne, 2001). It has been demonstrated that when data are not normally distributed, Chi-square values increase and standard errors are underestimated (Byrne, 2001), which may result in statistically significant estimated indices that are not actually significant. The distribution of data was assessed by procedures in AMOS based on Mardia's test of normalcy. Table 6 summarizes the results of Mardia's test of normality. The first row of table 6 shows that the lowest value for the grade level variable was 1.00 and the highest value was 3.00. Skewness for this variable was .09. The critical ratio, .58 , is the sample skewness divided by its standard error and it had a sample kurtosis of 1.40 and a critical ratio of -4.69 . The multivariate kurtosis value of 3.04 is Mardia's coefficient. Any kurtosis or skewness coefficient for an individual variable beyond +/2.00 indicates non-normality. Therefore, as the kurtosis value of school support is 3.93, 
beyond the $+/-2.00$ range, there is sufficient evidence that indicates a non-normal distribution for the data in the current study.

Mahalanobis d-squared values were also evaluated to identify individual data observations deviating farthest from the center of their distributions. Table 7 lists the top 10 observations in descending order of their Mahalanobis d-squared values. Observation number 59 is the observation farthest from the centroid with a Mahalanbois d-squared value of 33.19; its $\mathrm{p} 1$ value (.00) and $\mathrm{p} 2$ value (.03) in the adjacent columns indicate the probability that the d-squared value for any individual case would exceed the value of 33.19 is between $<.00$ and $<.03$. As confirmed by Byrne (2001), while small numbers in the $\mathrm{p} 1$ column are to be expected, similarly small numbers in the p2 column would indicate that significant deviations from the central distribution were present. This was the case in the current study. Examination of Mahalanobis d-squared values, then, confirmed the non-normal distribution of the data in the current study.

As with the results of Mardia's test of normality, significant non-normality indices were identified in this analysis. Procedures designed to address non-normality issues were implemented following the conclusion that the data for the current model were non-normally distributed. Boot-strapping was implemented with 2000 iterations to obtain accurate indices of total effects in the current analyses.

Notes for the Model and Model Fit Statistics. The following section in the output from AMOS informed the investigator that the minimum convergence was achieved, indicating that the estimation process yielded an admissible solution. This section of the output also listed the Chi-Square value (3.53), along with the degrees of freedom (3) and the probability value (.32) for the statistic. 
The null hypothesis postulated that the specification of the model was valid and the Chi-Square test evaluated the likelihood that this statement was true. The $p$ value associated with the Chi-Square statistic represented the likelihood of obtaining a ChiSquare value based on observed data that exceeds the Chi-Square value when the null hypothesis is true. Therefore, higher $p$ values associated with the Chi-Square statistic indicated closer fit between the hypothesized model and the observed data (Bollen, 1989). In the current study, a Chi-Square value of 3.53 with a $p$ value of .32 represented a good fit to the observed data. An examination of other indices of model fit also reflects that the hypothesized model was well represented by the sample data. Specifically, the CFI value of 1.00, RMSEA value of .03, and PCLOSE value of .57 were also indicative of a good model fit. These indicators of model fit also indicate goodness-of-fit between the hypothesized model and sample data. Inspection of the residuals and modification indices revealed no significant points of ill-fit in the model.

Standardized and Unstandardized Path Coefficients. Table 7 gives the 95\% confidence intervals for each unstandardized path coefficient. Table 8 gives the standardized path coefficients for the model. Figure 2 is a simplified model highlighting the significant paths from the experience of parental absence to academic achievement and educational expectations and includes parameter estimates for the structural coefficients in the model. Standardized coefficients appear on each path, with unstandardized coefficients in parentheses.

The model indicates an impact of the experience of parental absence on academic achievement via economic hardship. It also shows an impact of the experience of parental absence on educational expectations via economic hardship and level of 
perceived school support, as well as a direct impact of parental absence on educational expectations. The model also suggests an influence of educational expectations on academic achievement. In addition, as can be seen in tables 7 and 8 , the model documents separate significant influences of gender of the child, grade level of the child, language proficiency, and school support on participants’ academic achievement and educational expectations.

Thus, for children experiencing parental absence, economic hardship increased by .10 units $(p<.09)$. As economic hardship increased, academic achievement decreased by .10 units $(p<.06)$. Also, as economic hardship increased, perceived school support decreased by .10 units $(p<.09)$. With the increase of perceived school support, educational expectations increased by .24 units $(p<001)$. In addition, for children experiencing parental absence, educational expectations decreased by .13 units $(p<.03)$. Furthermore, as educational expectations of students increased, academic achievement increased by .24 units $(p<.001)$.

There were significant direct influences of child's gender on academic achievement, in that for males, academic achievement decreased by .28 units $(p<.001)$. Also, child's gender was found to influence academic achievement via economic hardship. For males, economic hardship decreased by .13 units $(p<.03)$ and as economic hardship increased, academic achievement decreased by .10 units $(p<.06)$. Child gender also impacted educational expectations via perceived school support. For males, perceived school support decreased by .12 units $(p<.05)$ and as school support increased, educational expectations increased by .24 units $(p<.001)$. 
The current study also found mediated relationships between grade level of the child and educational expectations. Grade level was found to influence educational expectations via parental school involvement. As students progressed through school, the level of parental school involvement decreased by .37 units $(p<.001)$. With the increase of parental school involvement, educational expectations increased by .16 units $(p<.01)$.

The current study also found direct and mediated relationships between language proficiency and academic achievement and educational expectations. Language proficiency was found to directly influence academic achievement and educational expectations. Students more proficient in the English language performed better academically and had higher expectations for their education. As language proficiency increased, academic achievement increased by .35 units $(p<.001)$ and educational expectations increased by .11 units $(p<.05)$. There were also paths in the model that were not statistically significant, meaning that the predictor variable did not account for a significant amount of variance in the outcome variable. For instance, while it was hypothesized that there would be a direct effect of the experience with parental absence on academic achievement, this path in the model was not significant $(p=.85)$. Also, the paths that hypothesized an effect of the experience of parental absence on school support $(p=.86)$ and level of parental school involvement $(p=.27)$ were not significant. This means that the experience of parental absence did not account for a significant amount of variance in school support or level of parental school involvement, and influenced academic achievement only indirectly through economic hardship.

Some of the hypothesized mediators in the current study were also not significant. For instance, level of parental school involvement did not have a significant impact on 
academic achievement $(p=.72)$. Also, the model found no significant impact of economic hardship on parental school involvement $(p=.82)$ or educational expectations $(p=.48)$. In addition, school support did not have a significant impact on academic achievement $(p=.94)$.

Total Effects. Of particular interest in the current study were the total (direct and indirect) effects of the experience of parental absence on the academic achievement and educational expectations of students. While the total effect of the experience of parental absence on academic achievement was not significant $(p>.05)$, it was significant for educational expectations $(p<.05)$. The total effect of parental absence on educational expectations was -.37 , meaning that including both direct (unmediated) and indirect (mediated) effects of parental absence on educational expectations, when parental absence increased by one unit, educational expectations decreased by .37 units.

There were also marginally significant total effects of the experience of parental absence on economic hardship $(p<.09)$. For those who experienced parental absence, economic hardship increased by .14. In addition, total effects were found for language proficiency, gender, grade level, economic hardship, school support, and level of parental school involvement on academic achievement and educational expectations Total effects can be found in Table 9 . 


\section{Chapter IV}

\section{Discussion}

In the current study, the academic achievement and educational expectations of immigrant students who had experienced parental absence as a result of serial migration, parental divorce, or parental death were examined. The aim of the study was to bridge the gap between two bodies of literature: (a) literature on the effects of parental absence on the academic achievement of children which has focused on parental separation due to parental divorce (Coley, 1998; Lamb, 1999; Gibson-Davis, 2008) and (b) literature on the academic achievement of immigrant children who often experience the absence of a parent as a consequence of the immigration process (Gaytan et al., 2007; Rousseau et al., 2004). Despite the value of these two bodies of research, our understanding of the factors that can impede or promote the academic achievement and educational expectations of immigrant students in the United States is constrained because the gap that exists has not been closed.

The current study had a primary goal of capturing and investigating the effects of parental absence for immigrant students from Spanish-speaking countries, as Latino students are more likely than other immigrants to have poor academic achievement and to drop out of school with no college aspirations. The study was also designed to specify the paths through which parental absence might affect academic achievement and educational expectations for immigrant students. Three research questions were proposed: (1) Are there significant differences in immigrant students from parent absent versus dual-parent homes in terms of educational expectations and academic achievement; (2) How do various experiences of parental absence, including reason for 
absence (immigration, separation/divorce, parental death), gender of absent parent, and length of absence affect academic expectations and achievement; and (3) To what extent does parental absence relate to academic expectations and achievement through potential mediating factors, including economic hardship, school support, and parental involvement? The results pertaining to each of these questions are discussed in the following sections.

Are there significant differences in immigrant students from parent absent versus dualparent homes in terms of educational expectations and academic achievement?

A multivariate analysis of variance (MANOVA) using parental absence as the independent variable and academic achievement and educational expectations as dependent variables was conducted to answer this question. The answer appears to be a qualified yes because the overall result was marginally significant. While previous research has found a relationship between parental absence and reduced academic achievement and lower educational expectations (Astone \& McLanahan, 1991; Coley, 1998; Hernandez, 2004; Lamb, 1999; Suarez-Orozco et al., 2009), the current study found a significant effect of parental absence for educational expectations but not academic achievement. Students who experienced parental absence had lower educational expectations than students from dual-parent homes. Although the same occurred for academic achievement, the results were not statistically significant.

Previous research that has been addressed to the academic achievement of Latino immigrant students has focused largely on immigrant students from Mexico residing in other parts of the United States, such as California and Texas (i.e., Suarez-Orozco \& Carhill, 2008; Suarez-Orozco et al., 2009), while the current study examined immigrant 
students from Cuba, Columbia, and Argentina. The public education systems in these countries likely provide students with some educational backgrounds that help them to fare well after migrating to the United States. That coupled with the highly developed ESOL classes in the Miami-Dade county school district could explain why results of the current study differ from those of previous research in terms of academic achievement. The lower expectations reported by participants in the current study may reflect the reality of barriers that immigrants face in obtaining higher education and employment, especially for undocumented immigrants. The current study did not assess if participants were undocumented or legal residents.

How do various experiences of parental absence affect academic expectations and achievement?

Hierarchical regression analyses were performed to examine how the reason for absence (immigration, separation/divorce, parental death), gender of absent parent (mom, dad, both), and length of absence affected academic achievement and educational expectations in immigrant students from these Spanish-speaking countries. The model used gender of child, age of child, and language proficiency of child as control variables.

For academic achievement, gender of the child, language proficiency, parental death, length of parental absence, the absence of both parents, and the interaction of gender of child and parental absence associated with serial migration were significant. In the current study, girls out performed boys, consistent with previous studies from both bodies of literature (Coney \& Mackey; McLanahan \& Teitler, 1999; Portes \& Rumbaut, 2001; Feliciano \& Rumbaut, 2005; Suarez-Orozco, 2004). Students in the current study who were not proficient with the English language performed worse than students who 
had mastered academic English skills, a result consistent with prior research (Genesee \& Gandara, 1999; Hernandez, 2004; Munoz-Sandoval, Cummins, Alvarado, \& Ruef, 1998). In the current study, parental absence caused by the death of a parent was significant for academic achievement in that students experiencing the death of a parent had lower academic achievement than those who did not lose a parent. This is consistent with studies that have documented a negative association between parental death and academic outcomes (Abdelnoor \& Hollins, 2004a; Abdelnoor \& Hollins, 2004b; Dowdney, 2000; Grollman, 1967; Van Eerdewegh, Bieri, Parilla \& Clayton, 1982). While there is minimal previous research regarding the effects of parental absence length on academic outcomes (e.g., Biller, 1970), the current study found that students who experienced prolonged periods of parental absence performed worse than students who did not experience prolonged parental absence. In addition, findings from the current study demonstrated that the combination of mother and father absence increased the risk of academic failure in their students. Previous research has found that father absence increases the chance of school disciplinary problems while mother absence reduces college expectations of children (Heard, 2007). In the current study, the absence of both parents hindered academic achievement where there was no significant effect for educational expectations. It may be that students who experienced prolonged parental absence and the absence of both of their parents were deprived of adult role models who could have invested resources that could help the child succeed (Heard, 2007; Valencia, 2000).

In addition, results also indicated an interaction effect of gender of child and parental absence resulting from serial migration, in that boys, but not girls, who 
experienced serial migration and parental separation performed worse academically than their peers. This finding is quite interesting in that the majority of research that has examined the effects of parental absence on academic outcomes has focused on parental divorce (e.g., Mullet \& Stolberg, 2001) with little examination of the effects of serial migration. Results of the current study demonstrate, however, that parental absence resulting from serial migration of immigrant students is an important factor in academic outcomes for boys. It may be that, for boys, separation from parents in the course of migration is viewed negatively and as unnecessary, causing distress in the child that affects his academic performance.

For educational expectations, language proficiency, parental absence from serial migration, parental death, and an interaction of grade level and parental absence resulting from serial migration were significant. As with academic achievement, students in the current study who were not proficient with the English language had lower educational expectations than those who were proficient. Numerous researchers have concluded that language barriers can be detrimental to the academic success of immigrant students (Genesee \& Gandara, 1999; Hernandez, 2004; Munoz-Sandoval, Cummins, Alvarado, \& Ruef, 1998), impacting reading and writing abilities as well as achievement test scores (Suarez-Orozco \& Carhill, 2008). Suarez-Orozco and Carhill concluded that language barriers may also hinder access to college for immigrant students. Findings from the current study expand this literature by demonstrating that language barriers impact student educational expectations regarding their future.

The finding that parental death impacts student educational expectations as well as academic achievement was not surprising. Although studies on the impact of parental 
death on student outcomes are limited, it has been documented that educational plans of children have been postponed or forgotten altogether after experiencing the death of a parent (Adolnoor \& Hollins, 2004b). Students who lost a parent had difficulty deciding on a career path and educational plans after such an experience in a prior study (Adolnoor \& Hollins, 2004b).

Students who experienced parental absence because of serial migration reported lower educational expectations than students who did not experience parental absence as a result of immigration to the United States. The current study, therefore, also demonstrates that serial migration is an important factor for educational expectations of immigrant students as well. The effects of serial migration on education expectations appear to vary based on the grade level of the student. Students in elementary school and middle school, but not high school, who experienced parental absence because of serial migration had lower educational expectations than students who did not experience parental absence associated with the migratory process.

Previous research has been inconsistent in regards to the impact of the child's age on academic outcomes. Some have speculated that parental absence occurring during childhood is more detrimental on academic outcomes than if it occurred during adolescence (Amato, 1996; McLanahan \& Teitler, 1999), while others have speculated parental absence during adolescence to be more detrimental (McCabe, 1997; McLanahan \& Bumpass, 1988; McLanahan \& Teitler, 1999; Sprague \& Kinney, 1997). Results of the current study suggest that the association between age of the child and negative outcomes associated with parental absence interacts with other factors, such as serial migration. It may be that older children and younger children view parental absence as a 
result of migration differently. Older children may see parental separation for this reason as a necessary step in the migratory process, viewing the absence as acceptable and temporary. Younger children may not be able to grasp this understanding of the separation and may experience stress as a result of parental absence, causing students to exhibit minimal expectations for themselves.

To what extent does parental absence relate to academic expectations and achievement through potential mediating factors, including economic hardship, school support, and parental involvement?

The extent to which parental absence relates to academic achievement and educational expectations through potential mediating factors, including economic deprivation, supportive school environment, and parental school involvement was assessed with structural equation modeling. The model also used gender, grade level, and language proficiency of the child as control variables. It was expected that parental absence would be associated with greater economic hardship, lower parental school involvement, and a less supportive school environment, which would mediate the relationship between parental absence and academic achievement and educational expectations. Overall, the model was a good fit to the data used in the current study, meaning that it was able to explain part of the relationship between parental absence and the academic achievement and educational expectations of immigrant students from three Spanish-speaking countries.

The model suggests an impact of the experience of parental absence on both academic achievement and educational expectations. Parental absence adversely affected academic achievement via economic hardship. The experience of parental absence was 
associated with an increase in family economic hardship, which is consistent with previous research (Heard, 2007; McLanahan \& Teitler, 1999). Increased economic hardship, then, led to lower academic achievement in students. Parental absence also impacted educational expectations via economic hardship as well as perceived school support. Economic deprivation was found to lead to a reduction in school support. This was not surprising as previous research has recognized that schools serving low-income, minority, and immigrant students tend to be at a disadvantage for academic success (Crosnoe, 2005; Suarez-Orozco \& Suarez-Orozco, 2001; Zhou, 1997). Reduced school support resulted in decreased educational expectations, consistent with previous research that has found a direct link between school support and student achievement (Woolley, 2007), especially that of immigrant students (Han, 2008). The direct effect of parental absence on decreased educational expectations is also consistent with previous findings (Astone \& McLanahan, 1991; Coley, 1998; Hernandez, 2004; Lamb, 1999; SuarezOrozco et al., 2009). The expectations of students were associated with their actual achievement, in that higher expectations led to higher achievement.

Significant relationships were also documented between gender, grade level, and language proficiency and academic achievement and educational expectations. Girls performed better academically than boys, which is consistent with previous research examining academic outcomes among youth from single-parent homes (Coney \& Mackey; McLanahan \& Teitler, 1999) and immigrant students (Portes \& Rumbaut, 2001; Feliciano \& Rumbaut, 2005; Suarez-Orozco 2004; Suarez-Orozco, Rhodes, \& Milburn, 2009; Suarez-Orozco et al., 2008). Gender also influenced educational expectations via economic hardship and perceived school support. Boys, in the current study, were more 
likely to report economic hardship than girls. Girls viewed their school environment as more supportive than boys, consistent with the findings of Way (2004). Increased perceived school support led to an increase in educational expectations in girls. Previous research has demonstrated how important a supportive school environment is for student success (Burchinal, Peisner-Feinberg, Pianta, \& Howes, 2002; Crosnoe, 2005; Gayton, Carhill, \& Suarez-Orozco, 2007; Han, 2008), especially that of Latino immigrant students (Han). The current study expands these findings to include future educational expectations.

Grade level influenced educational expectations through parental involvement in school activities. More specifically, as students increased in grade level, the level of parental school involvement decreased. Lower levels of parental school involvement were linked to decreased educational expectations. For immigrant students, the level of parental school involvement declines as children get older, which is consistent with prior findings (Kuperminc et al., 2007). Difficulties with the English language had a direct effect on the outcome measures. As students were more proficient in English, both their academic achievement (i.e., Genesee \& Gandara, 1999; Hernandez, 2004; MunozSandoval, Cummins, Alvarado, \& Ruef, 1998) and educational expectations increased. This may be because the more proficient they became with the English language, the more they saw the barriers against immigrants for higher education and career success decrease. 


\section{Limitations of Study}

There are some important limitations of the current study that merit discussion. These include: the difficulties inherent in cross-cultural research, lack of causal relationships, and limited generalizability.

Difficulties of Cross-cultural Research. Difficulties inherent in cross-cultural research include issues with measurement reliability and validity. However, these issues were addressed exhaustively during the data collection phase of the original three-year longitudinal study. Interviews were screened through a panel of advisors with expertise in research with immigrant populations. Measures were also pre-tested with children from groups represented in the study. Also, several research assistants from the target groups were used for development, translation, and improvement of survey questions to make sure that translations were comparable and meaningful across groups and all measures were back-translated prior to administration. Furthermore, the internal consistency reliabilities of measures used in this study were relatively high.

Inability to Make Causal Statements. In order to draw causal relations, the establishment of the temporal ordering of variables (i.e., a variable assumed to cause a change in an outcome should occur first), the correlations among variables, and other plausible alternative explanations should be ruled out (Pedhazur \& Schmelkin, 1991; Shadish, Cook, \& Campbell, 2002). Structural equation modeling enables researchers to test the fit of causal models to their data. A good fitting model then provides an indication that the hypothesized causal levels in the model are valid. However, it does not rule out other alternative models and the findings are correlational and in need of 
further verification. The current study documented correlational relationships rather than cause-effect relationships.

Limited Generalizability. The current study examined the academic achievement and educational expectations of immigrant students from three Spanish-speaking countries: Argentina, Columbia, and Cuba. Therefore, the extent to which results would generalize to other immigrant groups is unknown. Furthermore, limitations on sample size precluded analyzing results separately by country of origin group. There may be differences across groups within the sample that remain undiscovered.

\section{Significance of Study}

The current study is significant considering the current immigration trends in the United States. Immigrants from Spanish-speaking countries are currently the fastest growing immigrant population in the United States. By examining specifically Spanishspeaking immigrant students representing predominant waves of recent immigrants to South Florida, factors related to academic achievement and educational trajectories for this population have be identified. Measures can now be taken to reduce the negative impact of such factors and improve the academic achievement and educational trajectories of these students.

\section{Implications for Future Research}

The current study attempted to bridge two bodies of literature, that on the effects of parental absence on children and that of academic success among immigrant students, by examining reason for parental absence, factors related parental absence, and factors associated with academic outcomes for immigrant students from Spanish-speaking countries. Although the results of the current study helped to answer questions regarding 
the academic success of immigrant students, they also pose implications for future research directions within this domain.

Much research that has addressed academic outcomes of immigrant students has only touched on the effects of parental absence that results from serial migration. The current study found significant variation in academic achievement and educational expectations of immigrant students based on the experience of parental absence, as well as an important impact of serial migration. Serial migration and the parental absence that occurs with it is an experience that is unique to immigrant students. Serial migration, however, is only one aspect of the migratory process to the United States. Variation may also occur with the timing of migration, location of parents before and after migration, and possible additional caregivers prior to and post migration. In agreement with SuarezOrozco and Carhill (2008), one of the primary goals of research on immigrant students should be to capture the various migratory experiences and their effects on student performance. Future research needs to examine the divergence of the migration process more specifically in relation to the academic achievement and educational expectations of immigrant students from Spanish-speaking countries.

Future research also needs to clarify how parental absence associated with serial migration is viewed by the children involved and how the perception of parental separation impacts academic outcomes. It has been speculated that parental absence as a result of reasons other than parental divorce may be viewed differently by the children involved (Lamb, 1999). The current study suggests that parental absence that results from serial migration may be viewed differently by age and gender of the child; boys may view the absence more negatively than girls and younger children may view the 
absence more negatively than older children. This, in turn, affects the academic achievement and educational expectations of the child. 
Figure 1

Structural Equation Model

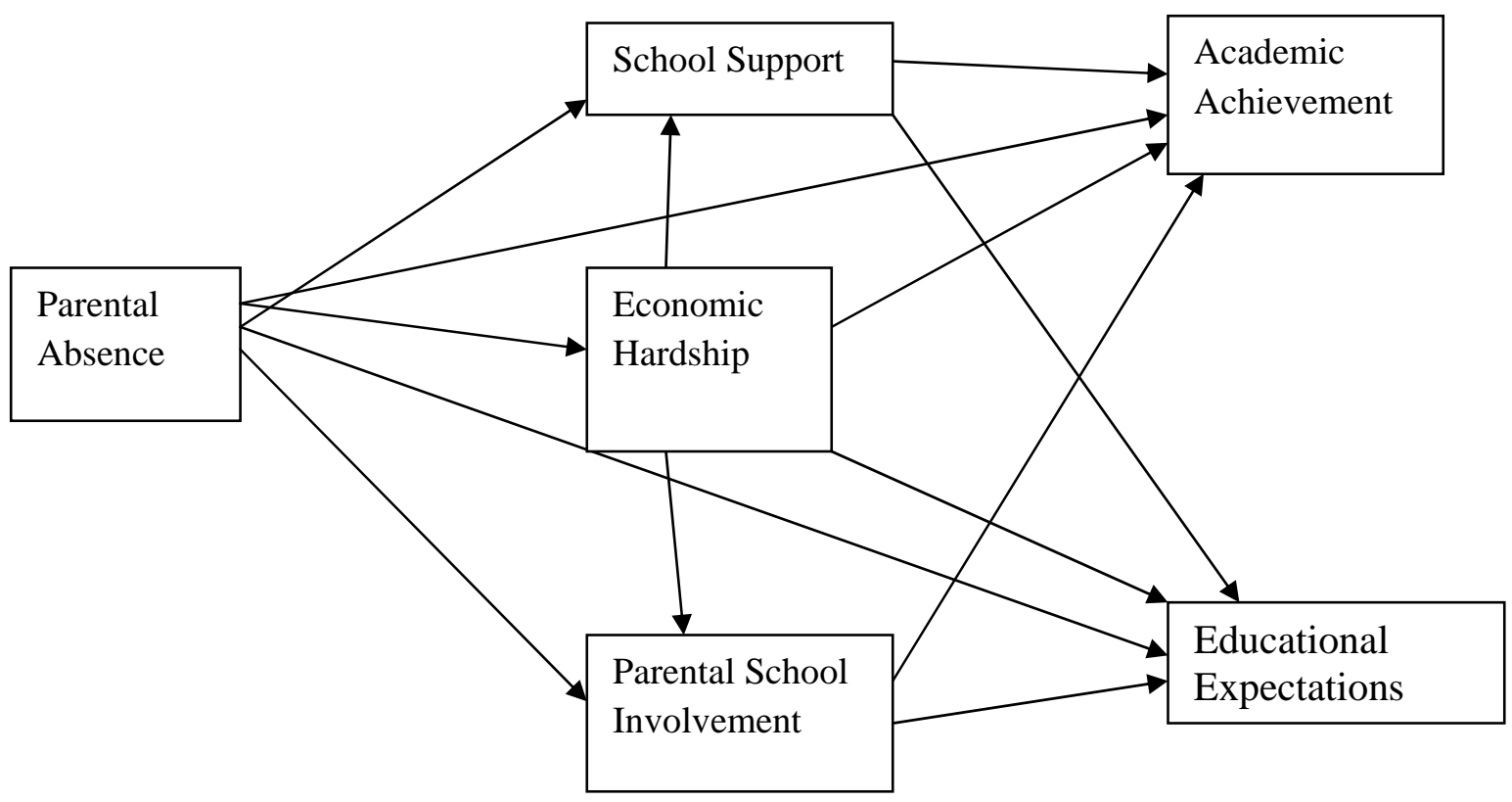


Table 1.

Descriptive Statistics for Variables

\begin{tabular}{|c|c|c|c|c|}
\hline Variable & $\mathrm{N}$ & $\%$ & $\mathrm{M}$ & SD \\
\hline Parental Absence & 193 & 72 & 1.72 & .45 \\
\hline Male Gender & 137 & 51 & & \\
\hline Grade & & & 1.95 & .79 \\
\hline Elementary & 91 & 34 & & \\
\hline Middle & 99 & 37 & & \\
\hline High-School & 78 & 29 & & \\
\hline Language & & & 4.08 & 1.06 \\
\hline \multicolumn{5}{|l|}{ Proficiency } \\
\hline Serial Migration & 101 & 38 & & \\
\hline Parental Divorce & 19 & 7 & & \\
\hline Parental Death & 16 & 6 & & \\
\hline Absence Length & & & .87 & .86 \\
\hline$<1 \mathrm{yr}$ & 68 & 25 & & \\
\hline$>1 \mathrm{yr}$ & 83 & 31 & & \\
\hline Mom Absent & 11 & 4 & & \\
\hline Dad Absent & 117 & 44 & & \\
\hline Both Absent & 26 & 10 & & \\
\hline School Support & & & 8.21 & 1.30 \\
\hline
\end{tabular}


Table 1. (continued).

Descriptive Statistics for Variables

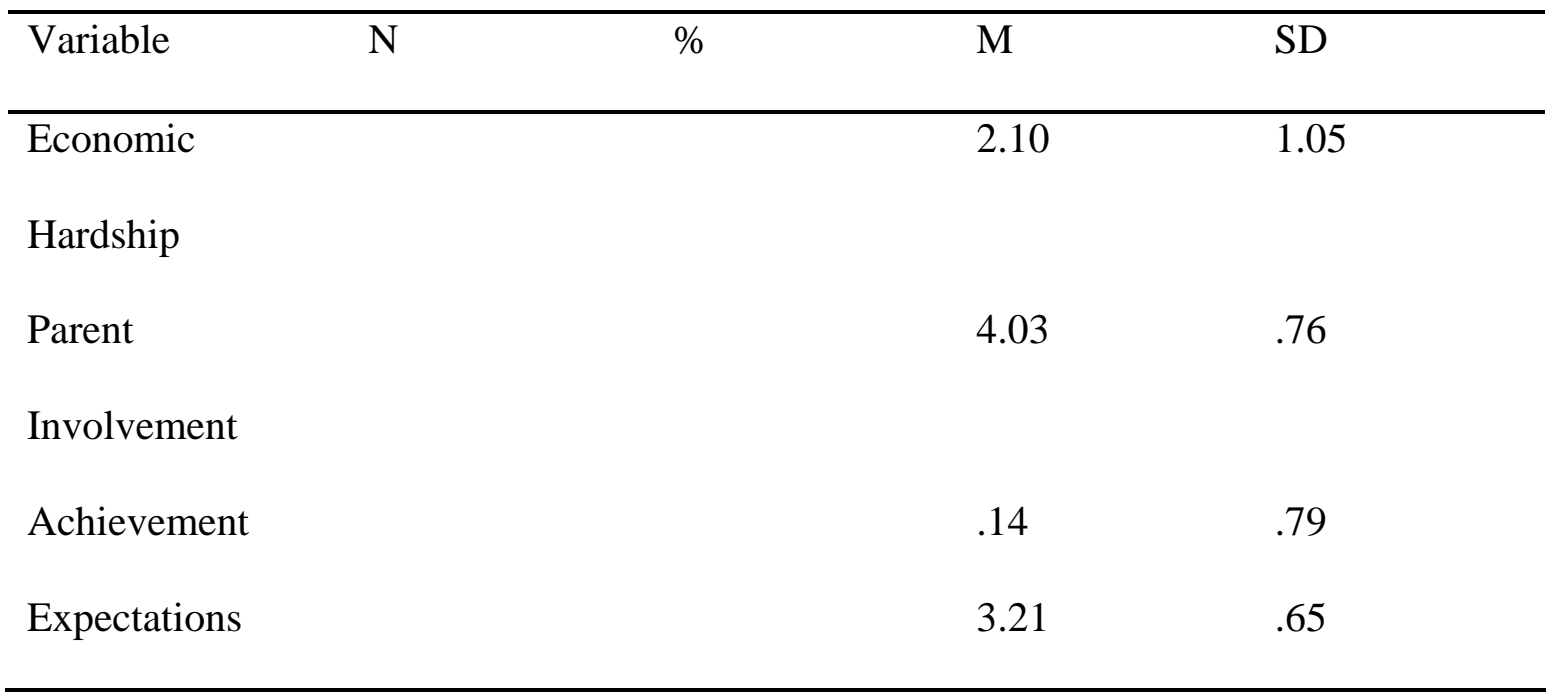


Table 2.

Intercorrelations of Study Variables

\begin{tabular}{|c|c|c|c|c|c|c|c|c|c|c|c|c|}
\hline Variable & 2 & 3 & 4 & 5 & 6 & 7 & 8 & 9 & 10 & 11 & 12 & 13 \\
\hline 1.Grade & -.04 & .02 & .02 & .00 & .07 & -.02 & .04 & .08 & .02 & .05 & -.02 & .01 \\
\hline 2.Gender & --- & .10 & -.04 & -.04 & .01 & .05 & .02 & .02 & .04 & .03 & .10 & $.32^{* *}$ \\
\hline 3.English & & --- & -.06 & .10 & -.11 & -.03 & -.07 & -.07 & -.01 & -.00 & $.12^{*}$ & $.42^{* *}$ \\
\hline Proficiency & & & & & & & & & & & & \\
\hline 4.Parental & & & --- & $-.21^{* *}$ & -.07 & $-.15^{* * *}$ & $.18^{* * *}$ & .02 & $.20^{* *}$ & -.04 & -.01 & -.04 \\
\hline Divorce & & & & & & & & & & & & \\
\hline $\begin{array}{l}\text { 5.Serial } \\
\text { Migration }\end{array}$ & & & & --- & $-.20^{* *}$ & $-.43^{* * *}$ & -.07 & -.08 & $.25^{* *}$ & -.10 & -.09 & .02 \\
\hline $\begin{array}{l}\text { 6.Parental } \\
\text { Death }\end{array}$ & & & & & --- & $-.14^{*}$ & $.24^{* *}$ & .11 & .00 & $.24^{* *}$ & -.11 & $-.15^{*}$ \\
\hline 7.Divorce and & & & & & & --- & $.47^{* *}$ & .11 & $.14^{*}$ & $.21^{* *}$ & .01 & .02 \\
\hline Serial Migration & & & & & & & & & & & & \\
\hline $\begin{array}{l}\text { 8.Absence } \\
\text { Length }\end{array}$ & & & & & & & --- & .07 & $.64^{* *}$ & $.34^{* *}$ & $-.12^{*}$ & $-.13^{*}$ \\
\hline 9.Mother & & & & & & & & --- & $-.18^{* * *}$ & -.07 & .08 & -.04 \\
\hline Absent & & & & & & & & & & & & \\
\hline $\begin{array}{l}\text { 10.Father } \\
\text { Absent }\end{array}$ & & & & & & & & & --- & $-.29^{* *}$ & -.06 & -.00 \\
\hline 11.Both Absent & & & & & & & & & & --- & -.11 & $-.12^{*}$ \\
\hline 12.Expectations & & & & & & & & & & & --- & $.31^{* *}$ \\
\hline 13.Achievement & & & & & & & & & & & & --- \\
\hline
\end{tabular}


Table 3.

Predicting Academic Achievement: Hierarchical Regression Analysis

\begin{tabular}{|c|c|c|c|c|}
\hline \multirow[b]{2}{*}{ Predictor } & \multicolumn{4}{|c|}{ Academic Achievement } \\
\hline & $B$ & $r^{2}$ & $F_{\text {chg }}$ & $r_{\text {chg }}^{2}$ \\
\hline Step 1: Control Variables & & & $24.10^{* * *}$ & .21 \\
\hline Gender & $.28^{* * *}$ & .08 & & \\
\hline Grade & .05 & .01 & & \\
\hline Language Proficiency & $.16^{* * *}$ & .12 & & \\
\hline Step 2: Reason for Absence & & & 1.15 & .01 \\
\hline Serial Migration & -.04 & .00 & & \\
\hline Parental Divorce & -.06 & .00 & & \\
\hline Migration and Divorce & -.05 & .00 & & \\
\hline Parental Death & $-.27^{* *}$ & .02 & & \\
\hline Step 3: Duration of Absence & & & $2.75^{*}$ & .01 \\
\hline Length of Absence & $-.09^{\#}$ & .01 & & \\
\hline Step 4: Parent Gender & & & 1.41 & .01 \\
\hline Mother & -.01 & .00 & & \\
\hline Father & -.04 & .00 & & \\
\hline Both Parents & $-.24^{*}$ & .00 & & \\
\hline Step 5: Interactions of Interest & & & .83 & .02 \\
\hline Gender X Serial Migration & $.30^{* *}$ & .02 & & \\
\hline
\end{tabular}

${ }^{* * *} p<.01 .{ }^{* *} p<.05 .{ }^{*} p=.06 . \# p=.09$

Note: Only significant interactions are reported. 
Table 4.

Predicting Educational Expectations: Hierarchical Regression Analysis

\begin{tabular}{|c|c|c|c|c|}
\hline \multirow[b]{2}{*}{ Predictor } & \multicolumn{4}{|c|}{ Educational Expectations } \\
\hline & $B$ & $r^{2}$ & $F_{\text {chg }}$ & $r_{\text {chg }}^{2}$ \\
\hline Step 1: Control Variables & & & $2.24^{\#}$ & .02 \\
\hline Gender & .11 & .01 & & \\
\hline Grade & -.01 & .00 & & \\
\hline Language Proficiency & $.07^{* *}$ & .01 & & \\
\hline Step 2: Reason for Absence & & & $2.26^{*}$ & .03 \\
\hline Serial Migration & $-.26^{* * *}$ & .02 & & \\
\hline Parental Divorce & -.16 & .00 & & \\
\hline Migration and Divorce & -.16 & .01 & & \\
\hline Parental Death & $-.41^{* *}$ & .02 & & \\
\hline Step 3: Duration of Absence & & & $1.04^{\#}$ & .00 \\
\hline Length of Absence & -.08 & .00 & & \\
\hline Step 4: Parent Gender & & & 1.39 & .01 \\
\hline Mother & .34 & .01 & & \\
\hline Father & .06 & .00 & & \\
\hline Both Parents & -.11 & .00 & & \\
\hline Step 5: Interactions of Interest & & & $1.66^{\#}$ & .06 \\
\hline Grade X Serial Migration & $.23^{* *}$ & .00 & & \\
\hline
\end{tabular}

${ }^{* * *} p<.01 .{ }^{* *} p<.05 .{ }^{*} p<.06 . \# p<.09$.

Note: Only significant interactions are reported. 
Table 5.

Madia's Test of Normality

\begin{tabular}{lcccccc}
\hline Variable & Min & Max & Skew & c.r. & Kurtosis & c.r. \\
\hline Grade & 1.00 & 3.00 & .09 & .58 & -1.40 & -4.69 \\
Parental Absence & .00 & 1.00 & -.98 & -6.55 & -1.04 & -3.47 \\
Language Proficiency & 1.00 & 5.00 & -.87 & -5.81 & -.31 & -1.02 \\
Gender & .00 & 1.00 & -.04 & -.30 & -2.00 & -6.68 \\
Economic Hardship & 1.00 & 12.67 & 1.69 & 11.28 & 1.16 & 3.86 \\
Parental School & 1.00 & 5.00 & -1.15 & -7.70 & 1.73 & 5.78 \\
Involvement & & & & & & \\
School Support & 2.00 & 9.00 & -1.97 & -13.19 & 3.93 & 13.12 \\
Expectations & 1.00 & 4.00 & -.56 & -3.72 & -.38 & -1.28 \\
Achievement & -2.20 & 1.39 & -.51 & -3.38 & -.52 & -1.75 \\
Multivariate & & & & & & \\
\end{tabular}


Table 6.

Top Ten Observations in Descending Order of Mahalanolois $d$-squared Values

\begin{tabular}{|c|c|c|c|}
\hline Observation Number & Mahalanolois d-squared & $\mathrm{p} 1$ & $\mathrm{p} 2$ \\
\hline 59 & 33.19 & .00 & .03 \\
\hline 223 & 30.86 & .00 & .00 \\
\hline 190 & 22.66 & .01 & .29 \\
\hline 25 & 22.63 & .01 & .12 \\
\hline 22 & 21.05 & .01 & .24 \\
\hline 86 & 20.87 & .01 & .15 \\
\hline 247 & 20.61 & .01 & .10 \\
\hline 63 & 19.56 & .02 & .20 \\
\hline 206 & 19.29 & .02 & .16 \\
\hline 83 & 18.89 & .03 & .17 \\
\hline
\end{tabular}


Table 7.

95\% Confidence Intervals for Unstandardized Path Coefficients

\begin{tabular}{|c|c|c|}
\hline Path & Estimate & $95 \% \mathrm{CI}$ \\
\hline Economic hardship $\leftarrow$ parental absence & .79 & -.14 to 1.56 \\
\hline Economic hardship $\leftarrow$ child gender & -.89 & -1.69 to -.06 \\
\hline School support $\leftarrow$ economic hardship & -.04 & -.09 to .01 \\
\hline Parental school involvement $\leftarrow$ economic hardship & .00 & -.03 to .03 \\
\hline School support $\leftarrow$ grade level & .04 & -.14 to .23 \\
\hline Parental school involvement $\leftarrow$ grade level & -.35 & -.46 to -.23 \\
\hline School support $\leftarrow$ parental absence & -.03 & -.35 to .32 \\
\hline Parental school involvement $\leftarrow$ parental absence & -.10 & -.28 to .09 \\
\hline School support $\leftarrow$ child gender & -.31 & -.62 to .01 \\
\hline Parental school involvement $\leftarrow$ child gender & -.01 & -.18 to .16 \\
\hline School support $\leftarrow$ language proficiency & .01 & -.13 to .17 \\
\hline Parental school involvement $\leftarrow$ language proficiency & -.04 & -.11 to .04 \\
\hline Educational expectations $\leftarrow$ school support & .12 & .06 to .18 \\
\hline Educational expectations $\leftarrow$ parental school involvement & .14 & .04 to .24 \\
\hline Educational expectations $\leftarrow$ economic hardship & .01 & -.01 to .03 \\
\hline Educational expectations $\leftarrow$ grade level & .04 & -.05 to .13 \\
\hline Educational expectations $\leftarrow$ parental absence & -.19 & -.35 to -.03 \\
\hline Educational expectations $\leftarrow$ child gender & -.07 & -.23 to .07 \\
\hline Educational expectations $\leftarrow$ language proficiency & .07 & -.01 to .15 \\
\hline
\end{tabular}


Table 7. (continued).

95\% Confidence Intervals for Unstandardized Path Coefficients

\begin{tabular}{lll}
\hline Path & Estimate & 95\% CI \\
\hline Academic achievement $\leftarrow$ school support & .00 & -.06 to .07 \\
Academic achievement $\leftarrow$ parental school involvement & -.02 & -.14 to .10 \\
Academic achievement $\leftarrow$ economic hardship & -.02 & -.05 to .00 \\
Academic achievement $\leftarrow$ grade level & -.01 & -.12 to .11 \\
Academic achievement $\leftarrow$ parental absence & -.02 & -.19 to .17 \\
Academic achievement $\leftarrow$ child gender & -.43 & -.61 to -.26 \\
Academic achievement $\leftarrow$ language proficiency & .26 & .19 to .33 \\
Academic achievement $\leftarrow$ educational expectations & .29 & .14 to .42 \\
\hline
\end{tabular}


Table 8.

Standardized Path Coefficients for Model

\begin{tabular}{|c|c|}
\hline Path & Estimate \\
\hline Economic hardship $\leftarrow$ parental absence & $.10^{\#}$ \\
\hline Economic hardship $\leftarrow$ child gender & $-.13^{* *}$ \\
\hline School support $\leftarrow$ economic hardship & $-.10^{\#}$ \\
\hline Parental school involvement $\leftarrow$ economic hardship & .01 \\
\hline School support $\leftarrow$ grade level & .02 \\
\hline Parental school involvement $\leftarrow$ grade level & $-.37^{* * * *}$ \\
\hline School support $\leftarrow$ parental absence & -.01 \\
\hline Parental school involvement $\leftarrow$ parental absence & -.06 \\
\hline School support $\leftarrow$ child gender & $-.12^{* *}$ \\
\hline Parental school involvement $\leftarrow$ child gender & -.00 \\
\hline School support $\leftarrow$ language proficiency & .01 \\
\hline Parental school involvement $\leftarrow$ language proficiency & -.05 \\
\hline Educational expectations $\leftarrow$ school support & $.24^{* * * *}$ \\
\hline Educational expectations $\leftarrow$ parental school involvement & $.16^{* * *}$ \\
\hline Educational expectations $\leftarrow$ economic hardship & .04 \\
\hline Educational expectations $\leftarrow$ grade level & .04 \\
\hline Educational expectations $\leftarrow$ parental absence & $-.13^{* *}$ \\
\hline Educational expectations $\leftarrow$ child gender & -.05 \\
\hline Educational expectations $\leftarrow$ language proficiency & $.11^{* *}$ \\
\hline
\end{tabular}

${ }^{* * * *} p<.001 .{ }^{* * *} p<.01 .{ }^{* *} p<.05 .{ }^{*} p<.06 . \# p<.09$. 
Table 8. (continued).

Standardized Path Coefficients for Model

\begin{tabular}{ll}
\hline Path & Estimate \\
\hline Academic achievement $\leftarrow$ school support & .00 \\
Academic achievement $\leftarrow$ parental school involvement & -.02 \\
Academic achievement $\leftarrow$ economic hardship & $-.10^{*}$ \\
Academic achievement $\leftarrow$ grade level & -.01 \\
Academic achievement $\leftarrow$ parental absence & -.01 \\
Academic achievement $\leftarrow$ child gender & $-.28^{* * * *}$ \\
Academic achievement $\leftarrow$ language proficiency & $.35^{* * * *}$ \\
Academic achievement $\leftarrow$ educational expectations & $.24^{* * * *}$ \\
\hline$* * * *<.001 . * * * p<.01 . *^{* *} p<.05 . * p<.06 . \# p<.09$. &
\end{tabular}


Figure 2

Simplified Model of Parental Absence on Academic Achievement and Educational Expectations

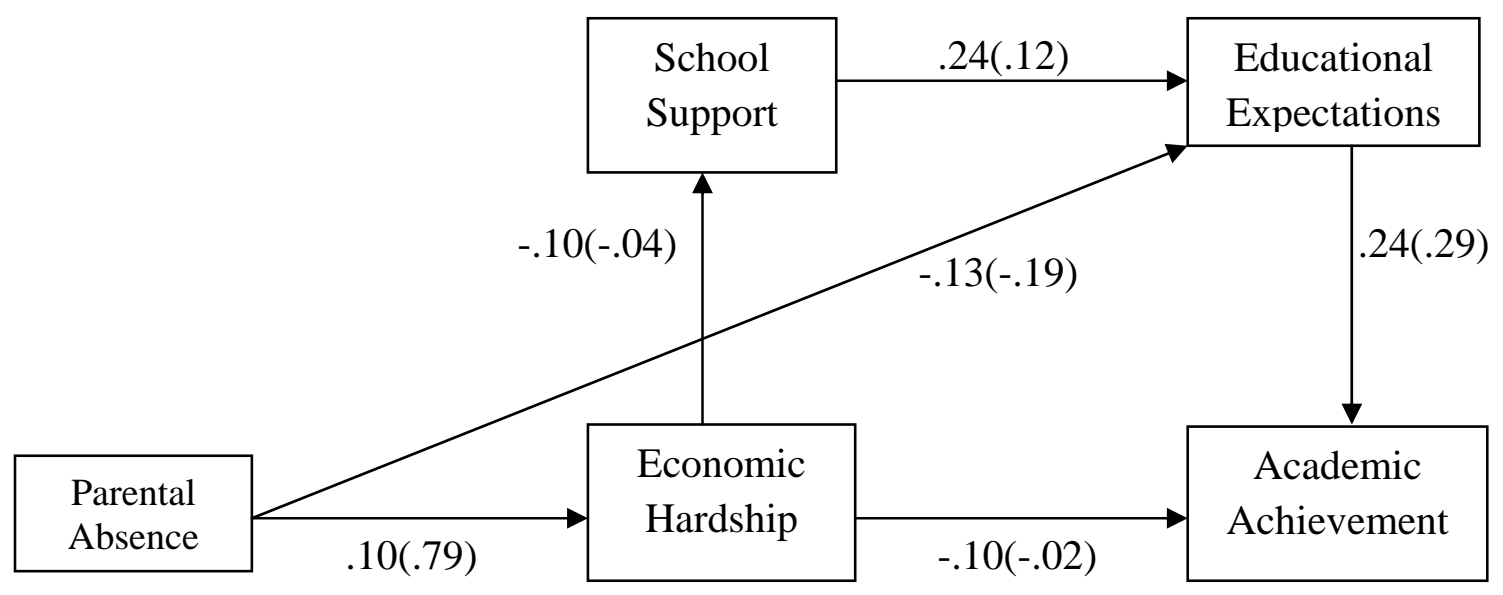


Table 9.

Total Effects in Model

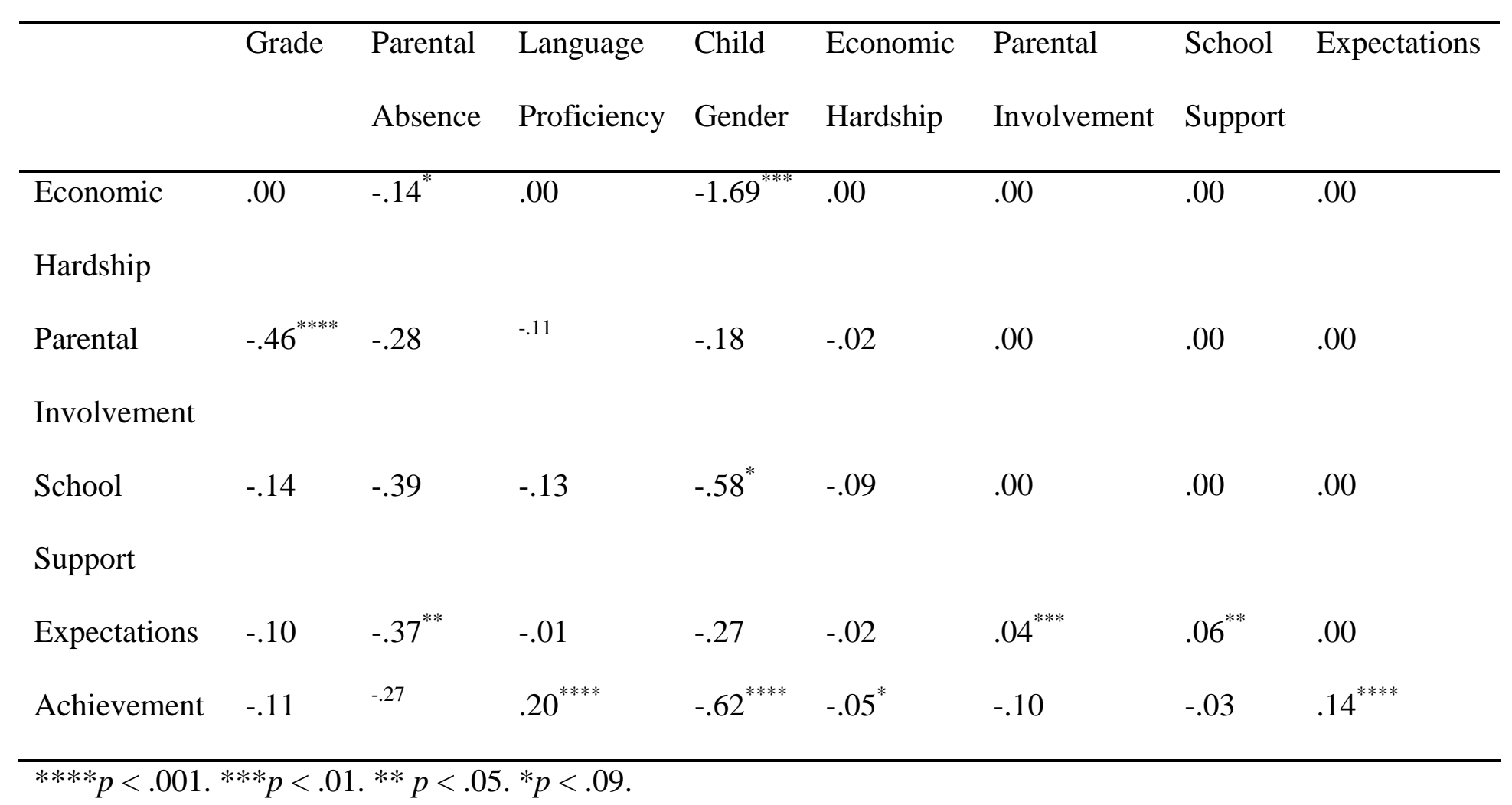




\section{REFERENCES}

Abdelnoor, A. \& Hollins, S. (2004a). The effect of childhood bereavement on secondary school performance. Educational Psychology in Practice, 20, 43-54.

Abdelnoor, A., \& Hollins, S. (2004b). How children display and cope at school after family bereavement. Educational and Child Psychology, 21, 85-94.

Alexander, K. L., Entwistle, D. R., \& Dauber, S. L. (1993). First-grade classroom behavior: It's short- and long-term consequences for school performance. Child Development, 64, 801-814.

Amato, P. R. (1996). Explaining the intergenerational transmission of divorce. Journal of Marriage and Family, 58, 628-640.

Amato, P. R., \& Sobolewski, J. M. (2001). The effects of divorce and marital discord on adult children’s psychological well-being. American Sociological Review, 66, 900-921.

Astone, N. M., \& McLanahan, S. S. (1991). Family structure, parental practices, and high school completion. American Sociological Review, 56, 309-320.

Barnard, W. M. (2004). Parent involvement in elementary school and educational attainment. Children and Youth Services Review. Special Issue: Promoting WellBeing in Children and Youth: Findings from the Chicago Longitudinal Study, 26, 39-62.

Barr, R., \& Lacey, C. (1998, April). Researching issues of immigration and education. (Conference report). Chicago, IL: The Spencer Foundation.

Battle, J. (2002). Longitudinal analysis of academic achievement among a nationwide sample of Hispanic students in one-versus dual-parent households. Hispanic Journal of Behavioral Sciences, 24, 430-447.

Bereczkei, T., \& Csanaky, A. (1996). Evolutionary pathway of child development. Human Nature, 7, 257-280.

Biller, H. (1970). Father absence and the personality development of the male child. Developmental Psychology, 2, 181-201.

Bishop, J., \& Lane, R. C. (2000). Father absence and the attitude of entitlement. Journal of Contemporary Psychotherapy, 30, 105-117.

Bollen, K. A. (1989). A new incremental fit for general structural equation models. SociologicalMethods and Research; 17, 303-316. 
Bollen, K. \& Long, S. (1993). Testing structural equation models. Newbury Park: Sage.

Burchinal, M. R., Peisner-Feinberg, E., Pianta, R. C., \& Howes, C. (2002). Development of academic skills from preschool through second grade: Family and classroom predictors of developmental trajectories. Journal of School Psychology, 40, 415436.

Byrne, B. M. (2001). Structural equation modeling with AMOS: Basic concepts, applications, and programming. Mahwah, NJ: Laurence Erlbaum Associates, Inc.

Castro, M. (2002). The new Cuban immigration in context. Miami: University of Miami North- South Center, North-South Agenda paper no. 58.

Coley, R. L. (1998). Children's socialization experiences and functioning in singlemother households: The importance of fathers and other men. Child Development, 69, 219-230.

Coll, C. G., \& Magnuson, K. (1997). The psychological experience of immigration: A developmental perspective. In A. Booth, A. C. Crouter, \& N. Landale (Eds.), Immigration and the family: Research and policy on U.S. immigrants (pp. 91131). Mahwah, NJ: Lawrence Erlbaum Associates, Inc.

Collier, M. W. (2004). Colombian migration to South Florida: A most unwelcome reception. Miami: Florida International University Latin American and Caribbean Center Working Paper Series.

Coney, N. S., \& Mackey, W. C. (1998). On whose watch? The silent separation of American children from their fathers. Journal of Sociology and Social Welfare, 25, $143-178$.

Conway, M. B., Christensen, T. M., \& Herlihy, B. (2003). Adult children of divorce and intimate relationships: Implications for counseling. Family Journal, 11, 364-373.

Cox, M. \& Harter, K. S. (2003). Parent-child Relationships. In Bornstein, Marc H.; Davidson, Lucy; Keyes, Corey L. M.; Moore, Kristin A. Well-being: Positive development across the life course. Crosscurrents in contemporary psychology. (pp. 191-204). Mahwah, NJ, US: Lawrence Erlbaum Associates Publishers.

Crosnoe, R. (2005). Double disadvantage or signs of resilience? The elementary school contexts of children from Mexican immigrant families. American Educational Research Journal, 42, 269-303.

Crul, M., \& Vermeulen, H. (2003). The second generation in Europe. International Migration Review, 37, 965-986. 
Dowdney, L. (2000). Annotation: Childhood bereavement following parental death. Journal of Child Psychology and Psychiatry, 41(7), 819-830.

Edelbrock, C. \& Achenbach, T. M. (1984). The teacher version of the child behavior profile: I. Boys aged 6-11. Journal of Consulting and Clinical Psychology, 52, 207-217.

Fagan, J. (2000). African American and Puerto Rican American parenting styles, paternal involvement, and Head Start children's social competence. Merrill-Palmer Quarterly, 46, 592-612.

Feliciano, C., \& Rumbaut, R. (2005). Gendered paths: Educational and occupational expectations and outcomes among adult children of immigrants. Ethnic and Racial Studies, 28, 1087-1118.

Florida's Office of Economic and Demographic Research. (2005). Characteristics of students by place of birth \& language spoken in the home: Florida public schools grades pk-12 2003-04 school year. Retrieved on 12/02/2008 from Office of Economic and Demographic Web site http://edr.state.fl.us/reports/education/ Characteristics\%20of\%20students\%20200204\%20-\%20Final\%20-\%20Aug\% 2029\%202005.pdf.

Fuligni, A. J. (1997). The academic achievement of adolescents from immigrant families: The roles of family background, attitudes, and behavior. Child Development, 68(2), 351-363.

Fuligni, A. J. (1998). The adjustment of children from immigrant families. Current Directions in Psychological Science, 7, 99-103.

Fuligni, A., Witkow, M., \& Garcia, C. (2005). Ethnic identity and the academic adjustment of adolescents from Mexico, Chinese, and European backgrounds. Developmental Psychology, 41, 799-811.

Furman, W., \& Buhrmester, D. (1985). Children's perceptions of the personal relationships in their social networks. Developmental Psychology, 21(6), 10161024.

Gándara, P. (1994). The impact of the educational reform movement on Limited English Proficient students. In B. McLeod (Ed.), Language and learning: Educating linguistically diverse students. (pp. 45-70) Albany, NY: SUNY Press.

Garibaldi, A. (1997). Four decades of progress and decline: An assessment of AfricanAmerican educational attainment. Journal of Negro Education, 66, 105-120. 
Genesee, F., \& Gandara, P. (1999). Bilingual education programs: A cross-national perspective. Journal of Social Issues, 55, 665-686.

Gibson-Davis, C. M. (2008). Family structure effects on maternal and paternal parenting in low- income families. Journal of Marriage and Family, 70, 452-465.

Gil, A. G., \& Vega, W. A. (1996). Two different worlds: Acculturation stress and adaptation among Cuban and Nicaraguan families. Journal of Social and Personal Relationships, 13(3), 435-456.

Gillis, J. R. (2000). Marginalization of fatherhood in western countries. Childhood: A Global Journal of Child Research, 7, 225-238.

Girard, C. \& Grenier, G. J. (2008). Insulating an ideology: The enclave effect on south Florida’s Cuban Americans. Latino Journal of Behavioral sciences p. 530-543.

Glenn, N. D., \& Kramer, K. B. (1987). The marriages and divorces of children of divorce. Journal of Marriage and Family, 49, 811-825.

Grollman, E. (1967). Explaining death to children. Boston: Beacon Press.

Han, W. J. (2008). The academic trajectories of children of immigrants and their school environments. Developmental Psychology, 44, 1572-1590.

Hao, L., \& Xie, G. (2002). The complexity and endogeneity of family structure in explaining childen’s misbehavior. Social Science Research, 31, 1-28.

Harker, K. (2001) Immigrant generation, assimilation, and adolescent psychological well being. Social Forces, 79, 969-1004.

Heard, H. E. (2007). Fathers, mothers, and family structure: Family trajectories, parent gender, and adolescent schooling. Journal of Marriage and Family, 69, 435-450.

Hernandez, D. J. (2004). Demographic change and the life circumstances of immigrant families. The Future of Children, 14, 17-47.

Hernandez, D. J., \& Charney, E. (Eds.) (1998). From generation to generation: The health and well-being of children in immigrant families. Washington, D.C.: National Academy Press. 2010 See: Current Population Reports, Series P25-1104, Population Projections of the United States, by Age,Sex, Race, and Latino Origin: 1993 to 2050.http://www.census.gov/population/www/pop-profile/natproj.html

King, G., Honaker, J., Joseph, A., \& Scheve, K. (2001). Analyzing incomplete political science data: An alternative algorithm for multiple imputation. American Political Science Review, 95, 49-69. 
Jaccard, J. \& Wan, C. (1996). LISREL analyses of interaction effects in multiple regression. Newbury Park: Sage.

Jaccard, J. (2010). Theory construction and model-building skills: a practical guide for social scientists. New York: Guilford Press.

James, D. C. S. (1997). Coping with a new society: The unique psychosocial problems of immigrant youth. Journal of School Health, 67(3), 98-102.

Kao, G., \& Tienda, M. (1995). Optimism and achievement: The educational performance of immigrant youth. Social Science Quarterly, 76, 1-19.

Karatzias, A., Power, K. G., Flemming, J., \& Lennan, F. (2002). The role of demographics, personality variables and school stress on predicting school satisfaction/dissatisfaction: Review of the literature and research findings. Educational Psychology, 22(1), 33-50.

Kopala, M., Esquivel, G., \& Baptiste, L. (1994). Counseling approaches for immigrant children: Facilitating the acculturative process. The School Counselor, 41, 352359.

Kuperminc, G. P., Darnell, A. J., \& Alvarez-Jimenez, A. (2007). Parent involvement in the academic adjustment of Latino middle and high school youth: Teacher expectations and school belonging as mediators. Journal of Adolescence, 31, 469483.

Lamb, M. E. (1999). Noncustodial fathers and their impact on the children of divorce. In R. A. Thompson \& P. R. Amato (Eds.), Postdivorce family: Children, parenting, and society (pp. 105-125). Thousand Oaks, CA: Sage Publications.

Landale, N. S., \& Oropesa, R. S. (2001). Father involvement in the lives of mainland Puerto Rican children: Contributions to nonresident, cohabiting and married fathers. Social Forces, 79, 945-968.

Laosa, L. M. (1997). Research perspectives on constructs of change: Intercultural migration and developmental transitions. In A. Booth, A. C. Crouter, \& N. Landale (Eds.), Immigration and the family: Research and policy on U.S. immigrants (pp. 133-148). Mahwah, NJ: Lawrence Erlbaum Associates, Inc.

Levitt, M. J., Crooks, N., Bustos, G. L., Santos, J., Telan, P., Silver, M. E., Branscum, E., \& Levitt, J. L. (1998, August). The social ecology of well-being in middle childhood. Presented at the meeting of the American Psychological Association: Scientific Affairs Focus on Science Session. San Francisco. 
Levitt, M. J., Levitt, J. L., Bustos, G. L., Crooks, N. A., Santos, J. D., Telan, P., \& Silver, M. E. (1999, April). The social ecology of achievement in pre-adolescents: Social support and school attitudes. Presented at the meeting of the American Educational Research Association, Montreal.

Martinez, C. R., Jr., DeGarmo, D. S., \& Eddy, J. M. (2004). Promoting academic success among Latino youths. Hispanic Journal of Behavioral Sciences, 26, 128-151.

McCabe, K. M. (1997). Sex differences in the long-term effects of divorce on children: Depression and heterosexual relationship difficulties in the young adult years. Journal of Divorce and Remarriage, 27, 123-135.

McLanahan, S., \& Bumpass, L. (1988). Intergenerational consequences of family disruption. American Journal of Sociology, 94, 130-152.

McLanahan, S. S., \& Carlson, M. J. (2002). Welfare reform, fertility, and father involvement. The Future of Children, 12, 146-165.

McLanahan, S., \& Teitler, J. (1999). The consequences of father absence. In M. E. Lamb (Ed.), Parenting and child development in “nontraditional” families (pp. 83-102). Mahwah, NJ: Lawrence Erlbaum Associates.

McLoyd, V. C., \& Wilson, L. (1991). The strain of living poor: Parenting, social support, and child mental health. In A. C. Houston (Ed.), Children in poverty: Child development and public policy (pp. 105-135). New York: Cambridge University Press.

Mullett, E., \& Stolberg, A. L. (2002). Divorce and its impact on the intimate relationships of young adults. Journal of Divorce and Remarriage, 38, 39-60.

Muñoz-Sandoval, A. F., Cummins, J., Alvarado, C. G., \& Ruef, M. L. (1998). Bilingual verbal ability tests: Comprehensive manual. Itasca, IL: Riverside.

National Center for Education Statistics. (2003). Status and trends in the Education of Hispanics. Retrieved 12/23/2008 from National Center for Educational Statistics Web site http://nces.ed.gov/pubsearch/pubsinfo.asp?pubid=2003008

National Center for Education Statistics. (2006). Digest of education statistics: 2005. Retrieved 12/23/2008 from http://nces.ed.gov/programs/digest/d05/tables/ dt05_008.asp.

National Center for Health Statistics. (1998). Births, marriages, divorces, and deaths for 1997. Monthly Vital Statistics Report (Vol. 46, No. 12). National Center for Health Statistics: Hyattsville, MD. Retrieved April 1, 2005 from http://www.cdc. gov/nchs/data/mvsr/mv46_12.pdf 
Orfield, G. (2002). Commentary. In M. Suárez-Orozco \& M. Paez (Eds.), Latinos: Remaking America (pp. 389-397). Berkeley: University of California Press.

Pérez, L. (2001). Growing up in Cuban Miami: Immigration, the enclave, and new generations. In R. G. Rumbaut, \& A. Portes (Eds.), Ethnicities: Children of immigrants in America (pp. 91-125). New York: Russell Sage Foundation.

Portes, A. \& MacLeod, D. (1996). Educational progress of children of immigrants: The roles of class, ethnicity, and school context. Sociology of Education, 69, 255275.

Portes, A., \& Rumbaut, R. G. (2001). Legacies: The story of the immigrant second generation. New York: Russell Sage Foundation.

Rivas-Drake, D., \& Mooney, M. (2008). Profiles of Latino Adaptation at Elite Colleges and Universities. American Journal of Community Psychology, 42, 1-16.

Roer-Strier, D., Striet, R., Este, E., Shimoni, R., \& Clark, D. (2005). Fatherhood and immigration: Challenging the deficit theory. Child and Family Social Work, 10, 315-329.

Rong, X. L., \& Preissle, J. (1998). Educating immigrant students: What we need to know to meet the challenges. Thousand Oaks, CA: Corwin Press.

Roscigno, V. (2000). Family/school inequality and African American/Hispanic achievement. Social Problems, 47, 266-291.

Ruiz-de-Velasco, J., \& Fix, M. E. (with Clewell, B. C.). (2001). Overlooked and underserved: Immigrant students in U.S. secondary schools. Washington, DC: Urban Institute.

Rousseau, C., Rufagari, M., Bagilishya, D., \& Measham, T. (2004). Remaking family life: Strategies for re-establishing continuity among Congolese refugees during the family reunification process. Social Science and Medicine, 59, 1095-1108.

Rumbaut, R. G. (1994). The crucible within: Ethnic identity, self-esteem, and segmented assimination among children of immigrants. International Migration Review, 28, 748-794.

Rumbaut, R. G. (1997). Ties that bind: Immigration and immigrant families in the United States. In A. Booth, Ann C. Crouter, \& Nancy Landale (Eds.), Immigration and the family (pp. 3-46). Mahwah, NJ: Erlbaum. 
Samdal, O., Nutbeam, D., Wold, B., \& Kannas, L. (1998). Achieving health and Educational goals through schools - a study of the importance of school climate and the student's satisfaction with school. Health Education Research, 13(3), 383-397.

Short, K. \& Johnston, C. (1997). Stress, maternal distress, and childrens adjustment following immigration: The buffering role of social support. Journal of Consulting and Clinical Psychology, 65, 494-503.

Siantz, M. L. (1997). Factors that impact developmental outcomes of immigrant children. In A. Booth, A. C. Crouter, \& N. Landale (Eds.), Immigration and the family: Research and policy on U.S. immigrants (pp. 149-161). Mahwah, NJ: Lawrence Erlbaum Associates, Inc.

Smith, A., Lalonde, R., \& Johnson, S. (2004). Serial migration and its implications for the parent-child relationship: A retrospective analysis of the experiences of the children of Caribbean immigrants. Cultural Diversity and Ethnic Minority Psychology, 10, 107-122.

Sprague, H. E., \& Kinney, J. M. (1997). The effects of interparental divorce and conflict on college students' romantic relationships. Journal of Divorce and Remarriage, 27, 85-104.

Suárez-Orozco, C. (2001). Afterward: Understanding and serving the children of immigrants. Harvard Educational Review, 71(3), 579-589.

Suárez-Orozco, C., \& Carhill, A. (2008). Afterword: New directions in research with immigrant families and their children. In H. Yoshikawa \& N. Way (Eds.), Beyond the family: Contexts of immigrant children's development. New Directions for Child and Adolescent Development, 121, 87-104.

Suárez-Orozco, C., Gaytán, F. X., Bang, H. J., Pakes, J., O'Connor, E., \& Rhodes, J. (2010). Academic trajectories of newcomer immigrant youth. Developmental Psychology, 46(3), 602-618. doi:10.1037/a0018201

Suárez-Orozco, C., \& Qin-Hilliard, D. B. (2004). The cultural psychology of academic engagement: Immigrant boys’ experiences in U.S. schools. In N. Way \& J. Chu (Eds.), Adolescent boys: Exploring diverse cultures of boyhood. New York: New York University Press.

Suarez-Orozco, C., Rhodes, J., \& Milburn, M. (2009). Unraveling the immigrant paradox: Academic engagement and disenganement among recently arrived immigrant youth. Youth Society, 41, 151-185. 
Suárez-Orozco, C., \& Suárez-Orozco, M. (1995). Transformations: Immigration, family life, and achievement motivation among Latino adolescents. Stanford CA: Stanford University Press.

Suárez-Orozco, C., \& Suárez-Orozco, M. (2001). Children of immigration (4th ed.). Cambridge, MA: Harvard University Press.

Suarez-Orozco, C., \& Suarez-Orozco, M. (in progress). Longitudinal Immigrant Student Adaptation Project. New York University, NY.

Suárez-Orozco, C., Suárez-Orozco, M., \& Todorova, I. (2008). Learning a new land: Immigrants students in American society. Cambridge, MA: Harvard University Press.

Suarez-Orozco, C., Todorova, I. L. G., \& Louis, J. (2002). Making up for lost time: The experience of separation and reunification among immigrant families. Family Process, 41, 625-673.

Toth, J. F., \& Xu, X. (1999). Ethnic and cultural diversity in fathers' involvement: A racial/ethnic comparison of African American, Hispanic, and White fathers. Youth \& Society, 31, 76-99.

U.S. Census Bureau. (2007). Persons obtaining legal permanent resident status by state of residence and region and country of birth: Fiscal year 2007. Retrieved 12/04/2008 from U.S. Census Bureau Web site http://quickfacts.census.gov/qfd/ States/12000.html

U.S. Department of Commerce, Bureau of the Census (2001). The Hispanic population in the United States. Current Population Reports, Series P20-535. Washington, DC: U.S. Government Printing Office.

U.S. Department of Homeland Security. (2007). Persons obtaining legal permanent resident status by region and country of birth: Fiscal year 1998 to 2007. Retrieved 12/21/2008 from Department of Homeland Security Web site http://www.dhs.gov/ximgtn/statistics/publications/LPR07.shtm

Valencia, R. (2000). Inequalities and the schooling of minority students in Texas. Hispanic Journal of Behavioral Sciences, 22, 445-459.

Van Eerdewegh, M.M., Bieri, M.D., Parilla, R.H. \& Clayton, P.J. (1982). The bereaved child. British Journal of Psychiatry, 140, 23-29.

Wallerstein, J. S., \& Kelly, J. B. (1980). Effects of divorce on the visiting father-child relationship. American Journal of Psychiatry, 137, 380-391. 
Waters, M. C. (1997). Immigrant families at risk: Factors that undermine chances for success. In Booth, A., Crouter, A. C., \& Landale, N. (Eds.), Immigration and the family: Research and policy on U.S. Immigrants (pp. 79-87). Mahwah, NJ: L. Erlbaum.

Way, N. (2004). Intimacy, Desire, and Distrust in the Friendships of Adolescent Boys. In N. Way \& J.Y. Chu (Eds.) Adolescent boys: Exploring diverse cultures of boyhood. (pp. 167-196). New York, NY, US: New York University Press.

Witkow, M., \& Fuligni, A. (2007). Achievement goals and daily school experiences among adolescents with Asian, Latino, and European American backgrounds. Journal of Educatinal Psychology, 99, 584-596.

Woolley, M. E., \& Bowen, G. L. (2007). In the context of risk: Supportive adults and the school engagement of middle school students. Family Relations, 56, 92-104.

Zac, L. (2002, February 24). Crisis sends Argentineans to Miami. BBC News. Retrieved July 6, 2005 from http://news.bbc.co.uk/1/hi/world/americas/1838465.stm.

Zhou, M. (1997). Growing up American: The challenge confronting immigrant children and children of immigrants. Annual Review of Sociology, 23, 63-95.

Zill, N., Morrison, D. R., \& Coiro, M. J. (1993). Long-term effects of parental divorce on parent-child relationships, adjustment, and achievement in young adulthood. Journal of Family Psychology, 7, 91-103. 
VITA

\section{CHRYSALIS LAMAE WRIGHT}

\section{Education}

Ph.D. (Doctoral Candidate)

Florida International University

Developmental Psychology

Dissertation: Parental Absence and Academic Achievement in Immigrant

Students (in progress)

Major Professor: Dr. Mary J. Levitt

Graduate Teaching Certificate (2010)

Academy for the Art of Teaching

Florida International University

M.A. (2006)

Middle Tennessee State University

Experimental Psychology, emphasis in Developmental Psychology

Thesis: Father Absence and College Students' Attitudes, Behaviors, and

Expectations Regarding Intimate Relationships

Major Professor: Dr. Michelle Boyer-Pennington

B.S. (2003)

Middle Tennessee State University

Psychology

Minors: Sociology and Criminal Justice

Advisor: Dr. Alan D. Musicant

Selected Awards \& Honors

2010 Dissertation Year Fellowship Award

Amount: 25,000.00

University Graduate School

Florida International University

2000 and 2003

The National Dean's List

Middle Tennessee State University

Selected Professional and University Service

2010 Reviewer: Student Grant Competition

Association for Psychological Science 
2009-current

University Representative: Student Caucus

Association for Psychological Science

2010 Presenter: Baby Bump or Bump the Baby

Presenter: Association for Psychological Science: Past, Present, \& Future

2009 Presenter: Using SPSS to facilitate research

Research Demonstration: Experience of Father Absence and Adult Children's

Courtship Behaviors and Intimate Relationship Attitudes

Selected Publications and Presentations

Wright, C. L. (2010). Family Structure Variations and Intimate Relationships in Adult Children. The New School Psychology Bulletin, 8, 16-29.

Wright, C. L. (in press). The Master Jugglers: Ten tips for balancing graduate school and family life. Association for Psychological Science, Observer

Wright, C. L. (under review). So many theories, so little time: An examination of theories on the intergenerational transmission of relationship instability. Marriage \& Family

Review

Wright, C. L. (in revision). Is it just a piece of paper? A review of the literature on cohabiting unions and intact homes. New School Psychology Bulletin

Wright, C. L. (under review). Courtship behaviors of Hispanic emerging adults: A structural equation modeling approach. Archive for the Psychology of Religion.

Wright, C. L. \& Levitt, M. J. (2010). Predicting Academic Performance in Immigrant Children from Spanish-Speaking Countries. Society for the Psychological Study of Social Issues.

Wright, C. L. \& Levitt, M. J. (2010). Educational Expectations of Children in Immigrant Families as a Function of Parental Absence. Association for Psychological Science.

Wright, C. L. \& Levitt, M. J. (2010). Predicting Courtship Behaviors of Emerging Adults from Immigrant and Nonimmigrant Families. Society for Research in Adult Development.

Wright, C. L., Levitt, M. J., Boyer-Pennington, M., \& Kim, J. K. (2009). Experience of Father Absence and Adult Children's Courtship Behaviors and Intimate Relationship Attitudes. Society for the Study of Human Development. 